Article

\title{
Analysis of Copper(II), Cobalt(II) and Iron(III) Sorption in Binary and Ternary Systems by Chitosan-Based Composite Sponges Obtained by Ice-Segregation Approach
}

\author{
Maria Valentina Dinu ${ }^{1, *(\mathbb{D})}$, Doina Humelnicu ${ }^{2} \mathbb{D}$ and Maria Marinela Lazar ${ }^{1}$ (D) \\ 1 “Mihai Dima" Department of Functional Polymers, "Petru Poni" Institute of Macromolecular Chemistry, \\ Grigore Ghica Voda Alley 41A, 700487 Iasi, Romania; mariperju@icmpp.ro \\ 2 Faculty of Chemistry, "Al. I. Cuza” University of Iasi, Carol I Bd. 11, 700506 Iasi, Romania; doinah@uaic.ro \\ * Correspondence: vdinu@icmpp.ro
}

Citation: Dinu, M.V.; Humelnicu, D.; Lazar, M.M. Analysis of Copper(II), Cobalt(II) and Iron(III) Sorption in Binary and Ternary Systems by Chitosan-Based Composite Sponges Obtained by Ice-Segregation Approach. Gels 2021, 7, 103. https:// doi.org/10.3390/gels7030103

Academic Editor: David Díaz Díaz

Received: 25 June 2021

Accepted: 22 July 2021

Published: 24 July 2021

Publisher's Note: MDPI stays neutral with regard to jurisdictional claims in published maps and institutional affiliations.

Copyright: () 2021 by the authors. Licensee MDPI, Basel, Switzerland. This article is an open access article distributed under the terms and conditions of the Creative Commons Attribution (CC BY) license (https:// creativecommons.org/licenses/by/ $4.0 /)$.

\begin{abstract}
With the intensive industrial activity worldwide, water pollution by heavy metal ions (HMIs) has become a serious issue that requires strict and careful monitoring, as they are extremely toxic and can cause serious hazards to the environment and human health. Thus, the effective and efficient removal of HMIs still remains a challenge that needs to be solved. In this context, copper(II), cobalt(II) and iron(III) sorption by chitosan (CS)-based composite sponges was systematically investigated in binary and ternary systems. The composites sponges, formed into beads, consisting of ethylenediaminetetraacetic acid (EDTA)- or diethylenetriaminepentaacetic acid (DTPA)functionalized CS, entrapping a natural zeolite $(\mathrm{Z})$, were prepared through an ice-segregation technique. The HMI sorption performance of these cryogenically structured composite materials was assessed through batch experiments. The HMI sorption capacities of CSZ-EDTA and CSZ-DTPA composite sponges were compared to those of unmodified sorbents. The Fe(III) ions were mainly taken up when they were in two-component mixtures with $\mathrm{Co}(\mathrm{II})$ ions at $\mathrm{pH} 4$, whereas $\mathrm{Cu}$ (II) ions were preferred when they were in two-component mixtures with $\mathrm{Co}(\mathrm{II})$ ions at $\mathrm{pH}$. The recycling studies indicated almost unchanged removal efficiency for all CS-based composite sorbents even after the fifth cycle of sorption/desorption, supporting their remarkable chemical stability and recommending them for the treatment of HMI-containing wastewaters.
\end{abstract}

Keywords: heavy metal ion sorption; binary system; ternary system; copper(II); cobalt(II); iron(III); chitosan; composite sponges; recycling

\section{Introduction}

Heavy metal ions (HMIs) occur naturally in the earth's crust. HMIs can enter into our bodies through food, drinking water and air. As essential elements, some HMIs (e.g., copper, zinc, iron) are vital in maintaining the metabolism of the human body when they are present in small amounts. At high concentrations, they are extremely toxic for living organisms or other biological systems [1]. The major sources of water pollution by HMIs are geological (natural) sources, mining and metal processing and industrial and domestic use of HMI salts (e.g., chromium in tanneries, copper and arsenic salts in pesticides or lead in petroleum products). Unfortunately, HMIs cannot be degraded and the only way to prevent their release into the environment is to recover and reuse them.

Copper ions ensure the proper function of many enzymes. However, copper salts are widely used as fungicides and germicides in agriculture and thus are commonly known as a source of risk for both humans and animals. Exceeding the tolerance level of $2.0 \mathrm{mg} / \mathrm{L}$ for copper can result in nausea, vomiting, diarrhea, liver poisoning and Wilson's disease [2]. Cobalt is another essential metal for both humans and animals. It is an active nutrient for bacteria, algae and fungi. Nevertheless, high levels of cobalt ions in water and food can reduce thyroid function or cause low blood pressure, hyperglycemia, paralysis, and bone 
defects [3]. Iron plays also a key role in human nutrition, helping to form hemoglobin, which carries the oxygen to all cells. It is also involved in cell metabolism and can be found in many enzymes of the body. Iron deficiency leads to anemia, fatigue and infections. In contrast to copper and cobalt, the ingestion of iron from drinking water is not directly associated with negative health effects. However, the iron sediments may contain traces of impurities or bacteria that can induce certain health issues [4].

In this context, the discharge of HMIs from aqueous solutions has been intensively carried out using various processes, including chemical precipitation, extraction with different solvents, flocculation, ion exchange, ultrafiltration, reverse osmosis and adsorption [5-10]. Among these, adsorption is considered a simple and efficient technique to remove HMIs from wastewaters [8-12]. A large variety of sorbent materials, such as metal oxides/hydroxides [13,14], zeolites [15,16], commercial or synthetic activated carbon [17,18], biomass [19], synthetic organic supports $[6,8,9]$, and unmodified or functionalized polysaccharides (chitosan, salecan, pullulan, alginate) [20-29] have been reported to remove HMIs from contaminated waters.

Lately, the employment of inexpensive and eco-friendly sorbents, such as renewable natural polymers, in the extraction and recovery of certain HMIs has drawn considerable interest [2,3,10,11,20-29]. Amongst these low-cost sorbents, chitosan (CS) displayed promising abilities to bind different HMIs due to the presence of numerous amino and hydroxyl groups in its structure $[2,20,27]$. Moreover, to increase CS chelation performance for HMIs, the grafting of various functional groups (8-hydroxyquinoline [3], thiourea [21], carboxylic [23], histidine [24]), and the construction of ion-imprinted CS-based sorbents [25,30] have been reported. Nevertheless, most of these sorbents were tested for removal of HMIs from single-component aqueous systems. As wastewaters consist of more complex mixtures of HMIs, the necessity of extending the application range of eco-friendly sorbents based on renewable resources is eagerly demanded. To date, there are just a few studies focused on multicomponent aqueous mixtures [31-33]. In this regard, we used here composite sponges, formed into beads, based on ethylenediaminetetraacetic acid (EDTA)or diethylenetriaminepentaacetic acid (DTPA)-functionalized chitosan (CS), entrapping a natural zeolite (Z), for removal of copper(II), cobalt(II) and iron(III) ions from binary and ternary aqueous mixtures. We systematically evaluated the influence of initial HMI concentration and $\mathrm{pH}$ on the sorption performance of CSZ-based sorbents. The HMI desorption and recycling abilities of CSZ-EDTA and CSZ-DTPA composites were also assessed in comparison to the unmodified CSZ sorbent.

\section{Results and Discussion}

To ensure a fast removal of HMIs from contaminated waters, the features of sorbents and their abilities to strongly bind ionic species should be considered. It is known that chelating agents such as aminopolycarboxylic acids form stable structures with HMIs. In this context, our study aimed to use glutaraldehyde (GA) cross-linked CSZ composite sponges bearing EDTA or DTPA functional groups (Figure 1A) for removal of $\mathrm{Cu}(\mathrm{II}), \mathrm{Co}(\mathrm{II})$ and $\mathrm{Fe}(\mathrm{III})$ ions from two- or three-component aqueous mixtures. All CS-based composite sorbents obtained through the ice-segregation approach exhibited a porous structure with walls arranged along the freezing direction (Figure 1B), which could allow easy and rapid access of HMIs towards ligand moieties. Due to the particularities of cryogelation, where the cross-linking polymerization reaction occurs in a highly concentrated non-frozen microphase, elastic and sponge-like materials with shape memory features are generated. The elemental analysis on the surfaces of CSZ, CSZ-EDTA and CSZ-DTPA composite sponges was performed using an energy dispersive $X$-ray detector (EDX) (Figure 1C). The EDX profiles were consistent with the presence of $\mathrm{C}, \mathrm{N}$ and $\mathrm{O}$ from $\mathrm{CS}$ and $\mathrm{Na}, \mathrm{Al}, \mathrm{Si}, \mathrm{K}$ and $\mathrm{Ca}$ from natural zeolite. The $\mathrm{Si} / \mathrm{Al}$ ratio within all CSZ-based composites was almost the same, indicating that the zeolite microparticles were not leached out during the functionalization process of CSZ matrix with EDTA or DTPA ligand groups (insets of Figure 1C). In addition, the weight percentage of $\mathrm{N}$ atoms increased for CSZ-EDTA and CSZ-DTPA composites, which proves the successful introduction of the EDTA and DTPA moieties. 


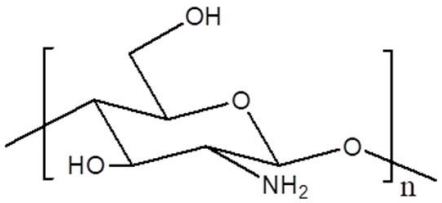

CS

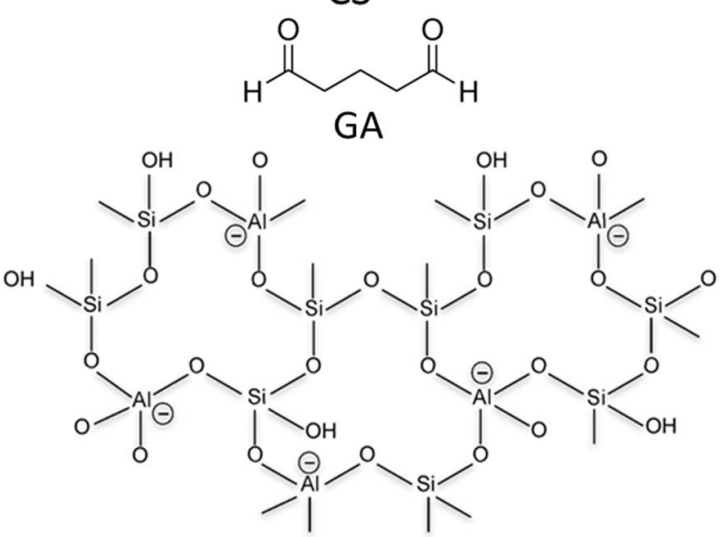

\section{Zeolite (Z)}
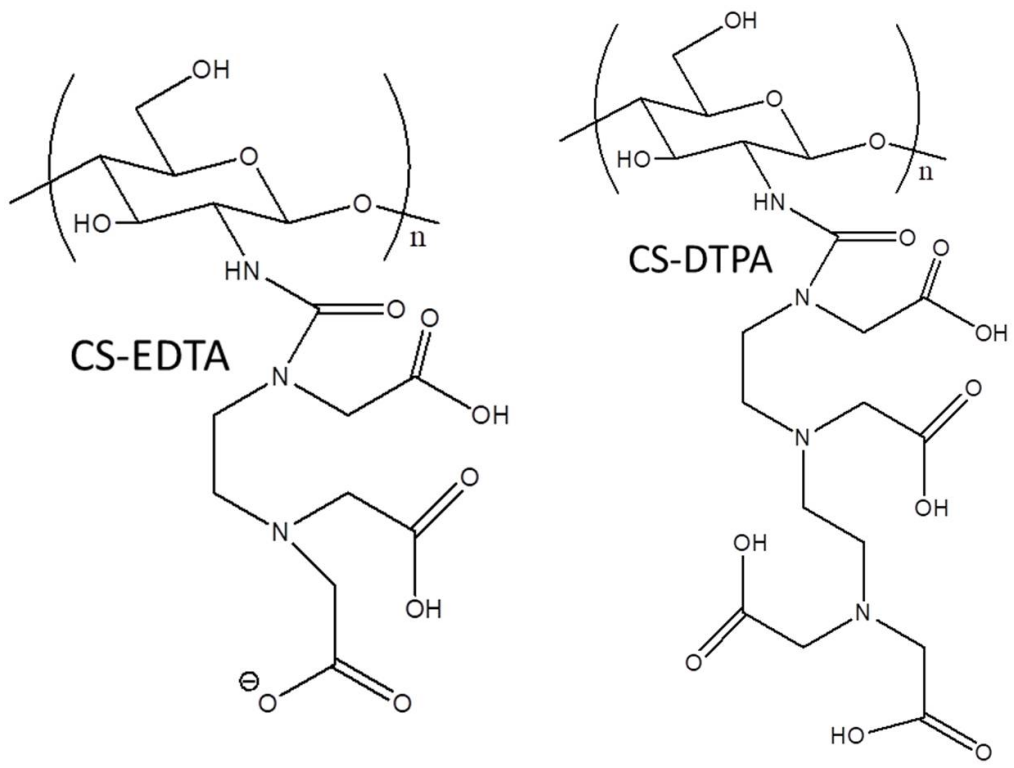

(A)
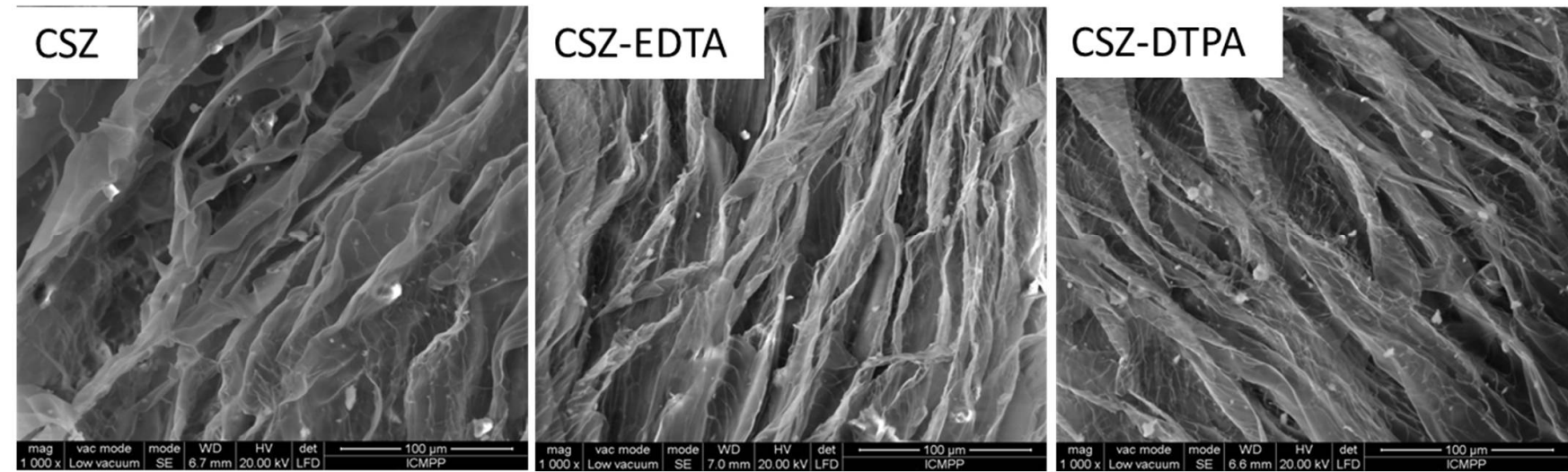

(B)

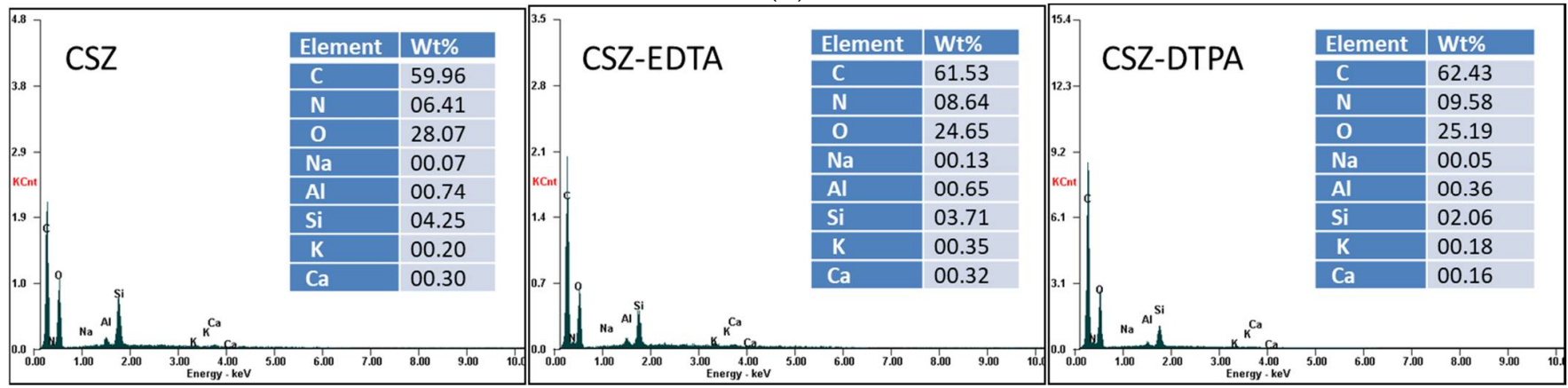

(C)

Figure 1. (A) Chemical structures of the chitosan (CS), glutaraldehyde (GA), zeolite (Z), ethylenediaminetetraacetic acidfunctionalized CS (CS-EDTA) and diethylenetriaminepentaacetic acid-functionalized CS (CS-DTPA) used to prepare the composite materials tested as sorbents for copper(II), cobalt(II) and iron(III) removal from binary and ternary systems. (B) SEM micrographs of CSZ, CSZ-EDTA and CSZ-DTPA composite sorbents; (C) EDX profiles and the corresponding weight percentages of elements present on the surface of CSZ, CSZ-EDTA and CSZ-DTPA composite sorbents.

The CSZ, CSZ-EDTA and CSZ-DTPA composites were systematically tested for sorption of $\mathrm{Cu}(\mathrm{II}), \mathrm{Co}(\mathrm{II})$ and $\mathrm{Fe}(\mathrm{III})$ ions at initial HMIs concentration values of $50 \mathrm{mg} / \mathrm{L}$ 
(Figures 2-4) and $200 \mathrm{mg} / \mathrm{L}$ (Figures 5-7), respectively. The study was also performed at $\mathrm{pH}=4$ and $\mathrm{pH}=6$ using both binary and ternary systems.
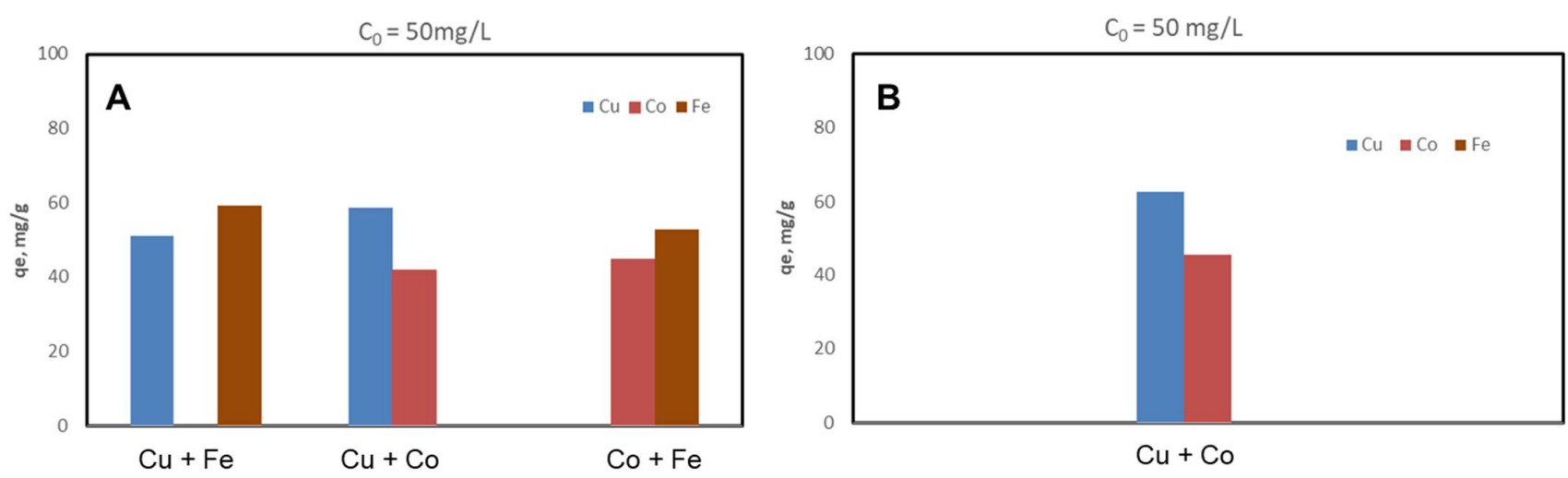

Figure 2. Sorption capacity and competitive sorption behavior of unmodified CS composite sorbent $(\mathrm{CSZ})$ at $\mathrm{pH}=4(\mathrm{~A})$ and $\mathrm{pH}=6(\mathrm{~B})$ in a binary system. Sorbent dosage $=0.4 \mathrm{~g} \mathrm{~L}^{-1}$; contact time $=24 \mathrm{~h} ; \mathrm{T}=21 \pm 1{ }^{\circ} \mathrm{C}$; initial $\mathrm{Cu}$ (II), $\mathrm{Co}$ (II) or $\mathrm{Fe}(\mathrm{III})$ concentration $=50 \mathrm{mg} \mathrm{L}^{-1}$. Note: At $\mathrm{pH}$ 6, only the system containing $\mathrm{Cu}$ and Co ions was studied because Fe ions precipitate at this value.
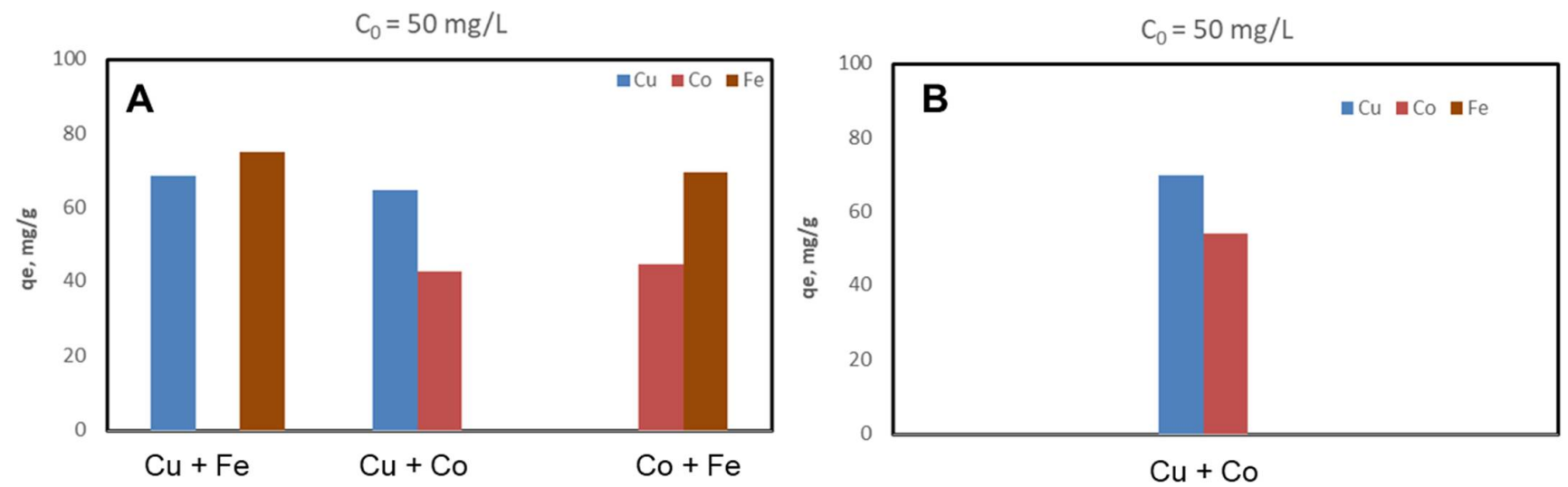

Figure 3. Sorption capacity and competitive sorption behavior of EDTA-functionalized CS composite sorbent (CSZ-EDTA) at $\mathrm{pH}=4(\mathrm{~A})$ and $\mathrm{pH}=6(\mathrm{~B})$ in a binary system. Sorbent dosage $=0.4 \mathrm{~g} \mathrm{~L}^{-1}$; contact time $=24 \mathrm{~h} ; \mathrm{T}=21 \pm 1{ }^{\circ} \mathrm{C}$; initial Cu(II), $\mathrm{Co}$ (II) or Fe(III) concentration $=50 \mathrm{mg} \mathrm{L}^{-1}$. Note: At $\mathrm{pH}$ 6, only the system containing $\mathrm{Cu}$ and Co ions was studied because Fe ions precipitate at this value.
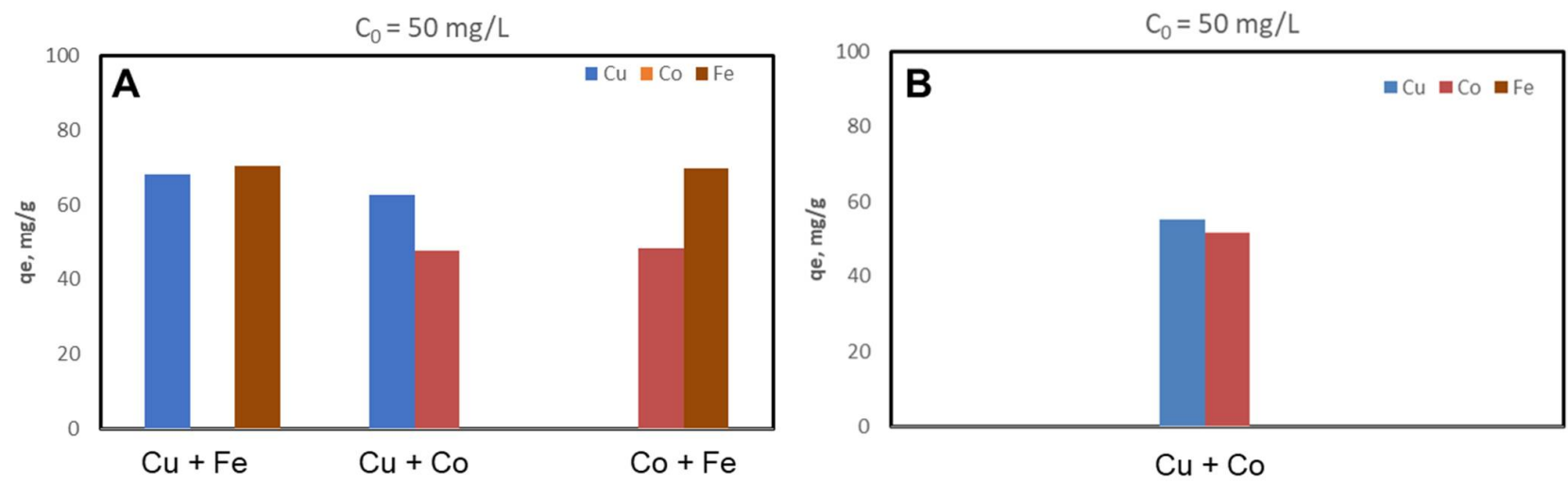

Figure 4. Sorption capacity and competitive sorption behavior of DTPA-functionalized CS composite sorbent (CSZ-DTPA) at $\mathrm{pH}=4(\mathbf{A})$ and $\mathrm{pH}=6(\mathbf{B})$ in a binary system. Sorbent dosage $=0.4 \mathrm{~g} \mathrm{~L}^{-1}$; contact time $=24 \mathrm{~h} ; \mathrm{T}=21 \pm 1^{\circ} \mathrm{C}$; initial $\mathrm{Cu}(\mathrm{II})$, $\mathrm{Co}(\mathrm{II})$ or $\mathrm{Fe}(\mathrm{III})$ concentration $=50 \mathrm{mg} \mathrm{L}^{-1}$. Note: At $\mathrm{pH}$ 6, only the system containing $\mathrm{Cu}$ and Co ions was studied because Fe ions precipitate at this value. 
$\mathrm{C}_{0}=200 \mathrm{mg} / \mathrm{L}$

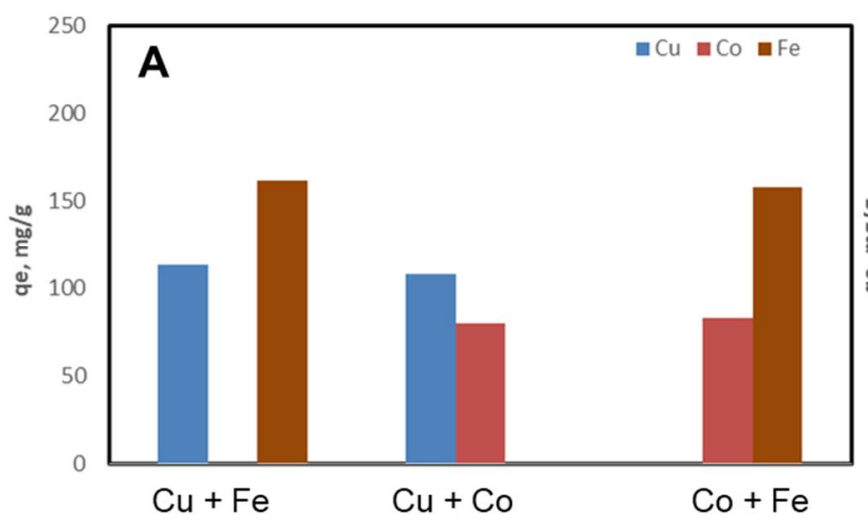

$\mathrm{C}_{0}=200 \mathrm{mg} / \mathrm{L}$

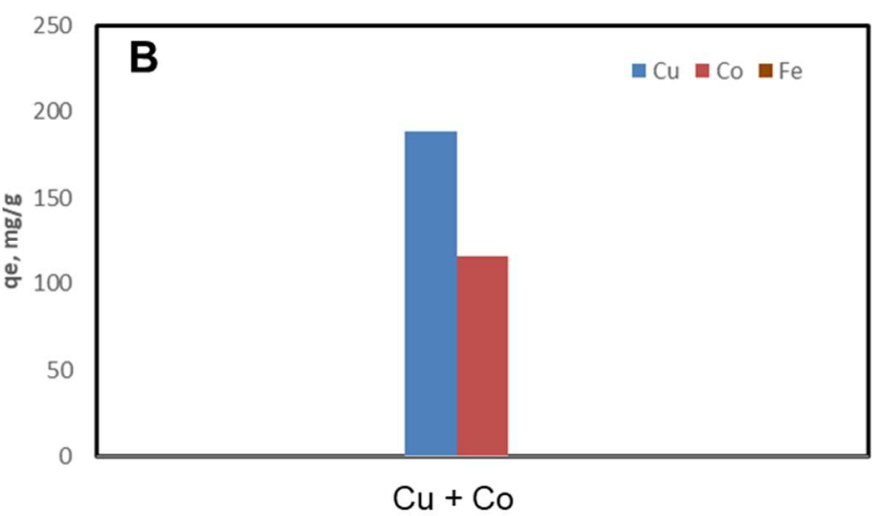

Figure 5. Sorption capacity and competitive sorption behavior of unmodified CS composite sorbent $(\mathrm{CSZ})$ at $\mathrm{pH}=4(\mathrm{~A})$ and $\mathrm{pH}=6(\mathrm{~B})$ in a binary system. Sorbent dosage $=0.4 \mathrm{~g} \mathrm{~L}^{-1}$; contact time $=24 \mathrm{~h} ; \mathrm{T}=21 \pm 1{ }^{\circ} \mathrm{C}$; initial $\mathrm{Cu}$ (II), $\mathrm{Co}$ (II) or $\mathrm{Fe}(\mathrm{III})$ concentration $=200 \mathrm{mg} \mathrm{L}^{-1}$. Note: At pH 6, only the system containing $\mathrm{Cu}$ and Co ions was studied because Fe ions precipitate at this value.
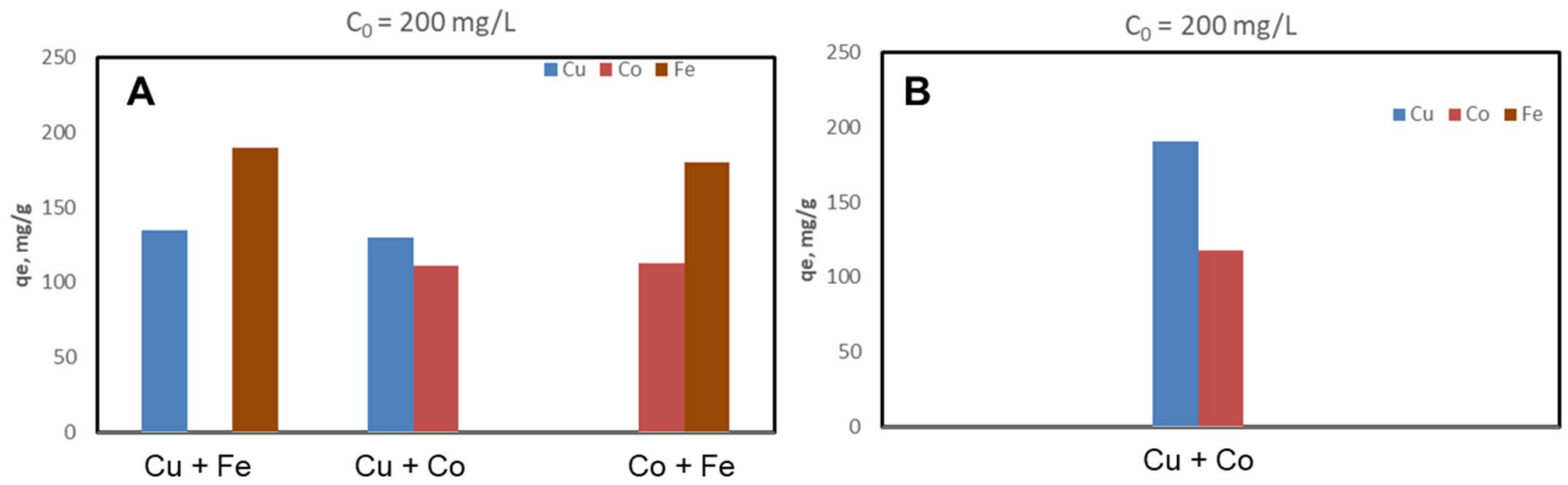

Figure 6. Sorption capacity and competitive sorption behavior of EDTA-functionalized CS composite sorbent (CSZ-EDTA) at $\mathrm{pH}=4(\mathrm{~A})$ and $\mathrm{pH}=6(\mathrm{~B})$ in a binary system. Sorbent dosage $=0.4 \mathrm{~g} \mathrm{~L}^{-1}$; contact time $=24 \mathrm{~h}$; $\mathrm{T}=21 \pm 1{ }^{\circ} \mathrm{C}$; initial $\mathrm{Cu}(\mathrm{II}), \mathrm{Co}(\mathrm{II})$ or $\mathrm{Fe}(\mathrm{III})$ concentration $=200 \mathrm{mg} \mathrm{L}^{-1}$. Note: At pH 6, only the system containing $\mathrm{Cu}$ and Co ions was studied because Fe ion precipitates at this value.
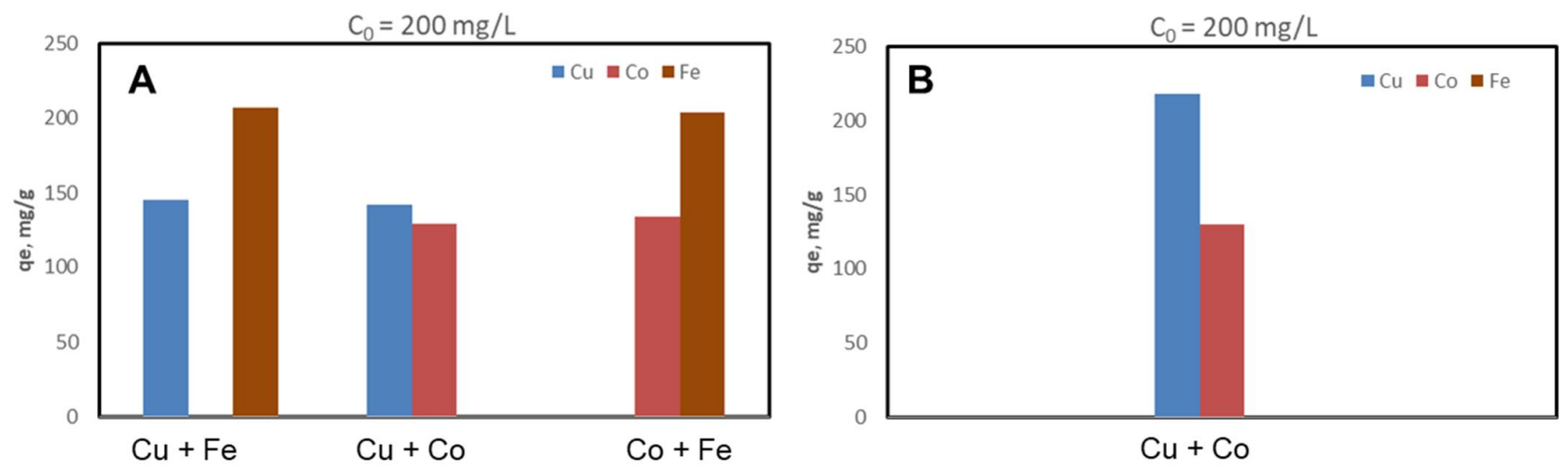

Figure 7. Sorption capacity and competitive sorption behavior of DTPA-functionalized CS composite sorbent (CSZ-DTPA) at $\mathrm{pH}=4(\mathrm{~A})$ and $\mathrm{pH}=6(\mathrm{~B})$ in a binary system. Sorbent dosage $=0.4 \mathrm{~g} \mathrm{~L}^{-1}$; contact time $=24 \mathrm{~h}$; $\mathrm{T}=21 \pm 1{ }^{\circ} \mathrm{C}$; initial $\mathrm{Cu}(\mathrm{II}), \mathrm{Co}(\mathrm{II})$ or $\mathrm{Fe}(\mathrm{III})$ concentration $=200 \mathrm{mg} \mathrm{L}^{-1}$. Note: At $\mathrm{pH}$ 6, only the system containing $\mathrm{Cu}$ and Co ions was studied because Fe ions precipitate at this value. 


\subsection{Sorption of HMIs in a Binary System}

The binding capacity of $\mathrm{Cu}(\mathrm{II}), \mathrm{Co}(\mathrm{II})$ and $\mathrm{Fe}(\mathrm{III})$ ions onto the CSZ-EDTA and CSZ-DTPA matrices was investigated in comparison to that of the unmodified CSZ sorbent. Batch experiments were first performed under competitive conditions using twocomponent synthetic aqueous mixtures. The sorption capacity and the competitive sorption behavior of all composites at $\mathrm{pH}=4$ and $\mathrm{pH}=6$ are presented in Figures 2-4.

At $\mathrm{pH}=4$, the $\mathrm{Fe}(\mathrm{III})$ ions were generally preferred when they were in a twocomponent mixture with $\mathrm{Co}(\mathrm{II})$ ions (Figures $2 \mathrm{~A}, 3 \mathrm{~A}$ and $4 \mathrm{~A}$ ). However, when the Fe(III) ions were in a binary mixture with $\mathrm{Cu}$ (II) ions, all CS-based composites exhibited almost the same sorption capacity for both HMIs (Figures 2A, 3A and 4A). When the $\mathrm{Cu}(\mathrm{II})$ ions were in competition with $\mathrm{Co}(\mathrm{II})$ ions, the $\mathrm{Cu}$ (II) ions were preferentially adsorbed onto CSZ, CSZ-EDTA and CSZ-DTPA composite sorbents, irrespective of the aqueous solution $\mathrm{pH}$ (Figures 2B, 3B and 4B).

An increase of the sorption capacity was observed for the EDTA- and DTPA-modified CSZ sorbents. For instance, the EDTA-functionalized sorbent exhibited a sorption capacity of $68.77 \mathrm{mg} \mathrm{Cu}$ (II) $/ \mathrm{g}$ and $75.07 \mathrm{mg} \mathrm{Fe}(\mathrm{III}) / \mathrm{g}$, while the unmodified CSZ sorbent showed a sorption capacity of only $51.23 \mathrm{mg} \mathrm{Cu}(\mathrm{II}) / \mathrm{g}$ and $59.31 \mathrm{mg} \mathrm{Fe}(\mathrm{III}) / \mathrm{g}$.

A similar behavior was also observed when the initial HMI concentration increased from 50-200 mg/L (Figures 5-7).

All CS-based composite sorbents in acidic medium $(\mathrm{pH}=4)$ showed a high affinity for $\mathrm{Fe}(\mathrm{III})$ ions when they were in mixture with $\mathrm{Cu}$ (II) or $\mathrm{Co}(\mathrm{II})$ ions (Figures $5 \mathrm{~A}, 6 \mathrm{~A}$ and $7 \mathrm{~A}$ ). The experimental $\mathrm{q}_{\mathrm{e}}$ values for $\mathrm{Fe}(\mathrm{III})$ ion removal from their mixture with $\mathrm{Cu}$ (II) ions by CSZ, CSZ-EDTA and CSZ-DTPA sorbents were $161.60 \mathrm{mg} / \mathrm{g}, 189.61 \mathrm{mg} / \mathrm{g}$ and $206.65 \mathrm{mg} / \mathrm{g}$, respectively. The $\mathrm{q}_{\mathrm{e}}$ values for $\mathrm{Fe}(\mathrm{III})$ ions sorption slightly decreased when they were taken up from the binary system with $\mathrm{Co}(\mathrm{II})$. Thus, the amounts of Fe(III) retained by CS-based composite sorbents ranged from $157.56 \mathrm{mg} / \mathrm{g}$ to $203.75 \mathrm{mg} / \mathrm{g}$ (Figures 5A, 6A and 7A).

At $\mathrm{pH}=6, \mathrm{Cu}(\mathrm{II})$ ions were mainly retained over $\mathrm{Co}(\mathrm{II})$, and the $\mathrm{Cu}(\mathrm{II})$ sorption capacities increased from $188.31 \mathrm{mg} / \mathrm{g}$ for CSZ sorbent (Figure 5B) to $190.64 \mathrm{mg} / \mathrm{g}$ for CSZ-EDTA sorbent (Figure 6B) and to $218 \mathrm{mg} / \mathrm{g}$ for CSZ-DTPA sorbent (Figure 7B).

\subsection{Sorption of HMIs in Ternary System}

The study for the ternary system was only performed at $\mathrm{pH}=4$, using an initial HMI concentration of $50 \mathrm{mg} / \mathrm{L}$ (Figure $8 \mathrm{~A}$ ) and of $200 \mathrm{mg} / \mathrm{L}$ (Figure 8B). At $\mathrm{pH}=6$ it was not possible to prepare a ternary system since $\mathrm{Fe}(\mathrm{III})$ ions precipitate at this value.

Comparing the $\mathrm{q}_{\mathrm{e}}$ values of CSZ, CSZ-EDTA and CSZ-DTPA composite sorbents, the CSZ-DTPA showed the highest sorption capacity for Fe(III) ions, i.e., $61.1 \mathrm{mg} / \mathrm{g}$ (Figure $8 \mathrm{~A}$ ) and $188.03 \mathrm{mg} / \mathrm{g}$ (Figure 8B). The affinity sequence of all CS-based composites was: $\mathrm{Fe}(\mathrm{III})>\mathrm{Cu}(\mathrm{II})>\mathrm{Co}(\mathrm{II})$, regardless of the $\mathrm{pH}$ of the aqueous mixture. The possible interactions between HMIs and the functional groups of composite sponges are depicted in Figure 9. The most active coordination centers for HMIs are the $-\mathrm{NH}_{2}$ and $-\mathrm{OH}$ groups of CS (Figure 9A). The - $\mathrm{COOH}$ groups from EDTA or DTPA bind the HMIs throughout the electrostatic interactions (Figure 9B,C), while the natural zeolite is involved in an ion exchange process for HMI binding.

\subsection{HMIs Desorption and Sorbent Recycling}

The recycling ability of the sorbents and the recovery of HMIs are very important factors that should be assessed in order to evaluate the cost-effectiveness of a sorption process in wastewater treatment $[31,33]$. In this study, the HMIs adsorbed onto CS-based composite sorbents were eluted with $0.1 \mathrm{M} \mathrm{HCl}$ solution and, before another sorption cycle, the sorbents were regenerated with $0.1 \mathrm{M} \mathrm{NaOH}$. 


\section{$\mathrm{C}_{0}=50 \mathrm{mg} / \mathrm{L}$}
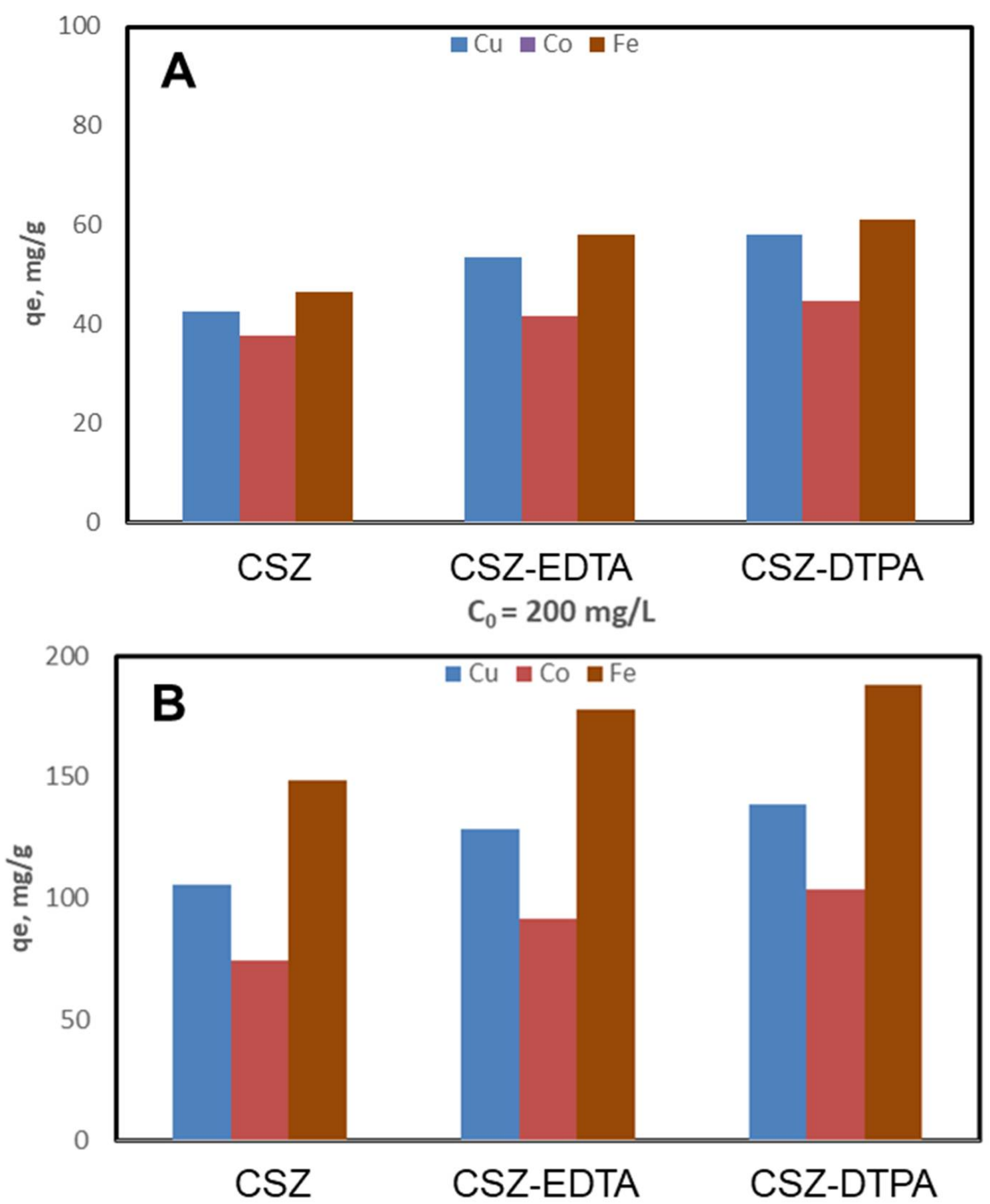

Figure 8. Sorption capacity and competitive sorption behavior of CSZ, CSZ-EDTA and CSZ-DTPA composite sorbents toward $\mathrm{Cu}(\mathrm{II}), \mathrm{Co}(\mathrm{II})$ and $\mathrm{Fe}(\mathrm{III})$ in a ternary system with an initial HMI concentration of $50 \mathrm{mg} / \mathrm{L}$ (A) or $200 \mathrm{mg} / \mathrm{L}$ (B). Sorbent dosage $=0.4 \mathrm{~g} \mathrm{~L}^{-1} ; \mathrm{pH}=4$; contact time $=24 \mathrm{~h} ; \mathrm{T}=21 \pm 1{ }^{\circ} \mathrm{C}$.

The CSZ, CSZ-EDTA and CSZ-DTPA composite sorbents were involved in five successive sorption/desorption cycles using either $\mathrm{pH} 4$ (Figure 10A,B, Figure 11A,B and Figure 12A,B) or pH 6 (Figure 10C,D, Figure 11C,D and Figure 12C,D) and an initial HMI concentration of $50 \mathrm{mg} / \mathrm{L}$ (Figure 10A,C and Figure 11A,C) or $200 \mathrm{mg} / \mathrm{L}$ (Figure 10B,D, Figure 11B,D and Figure 12B,D). 

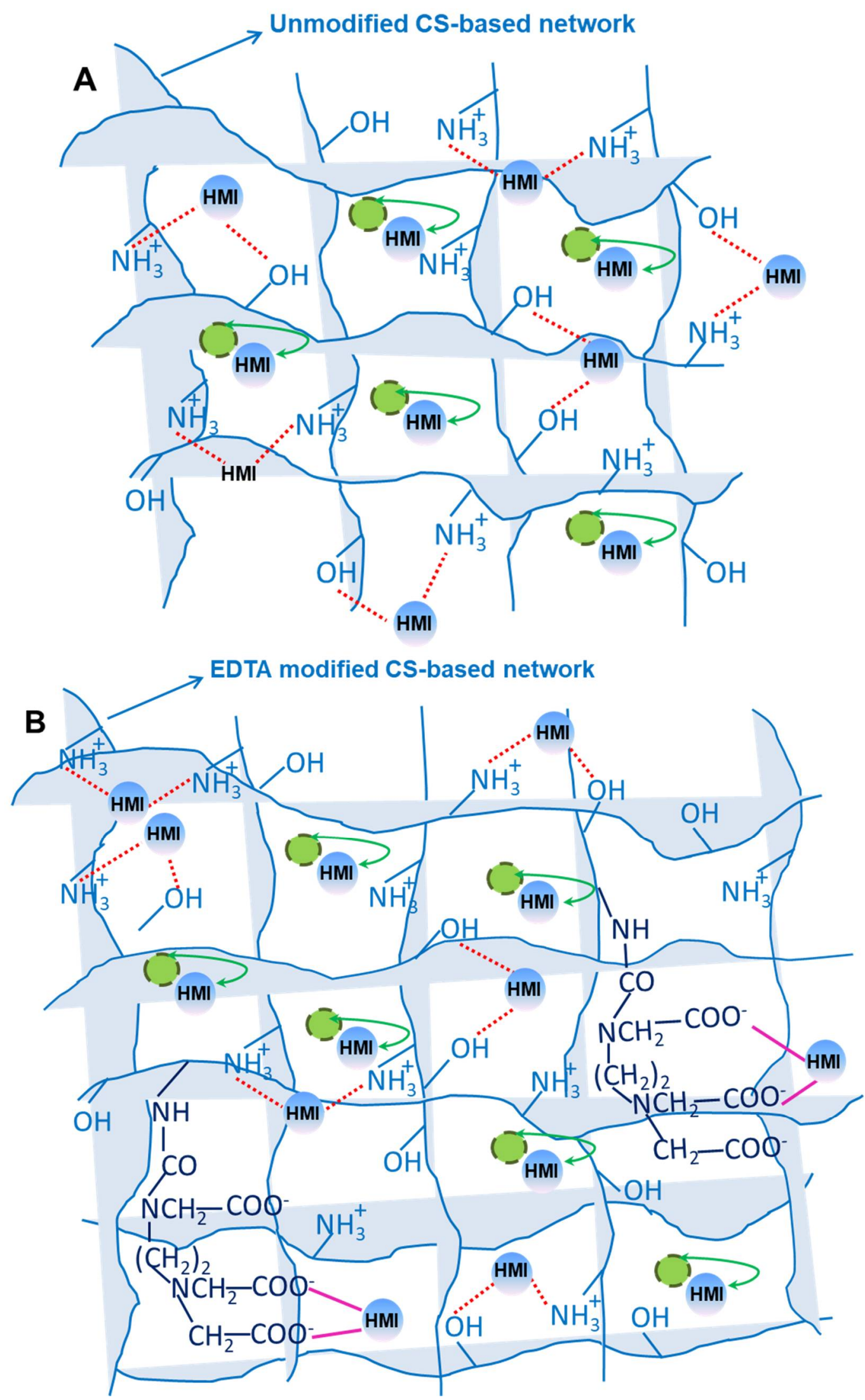

Figure 9. Cont. 


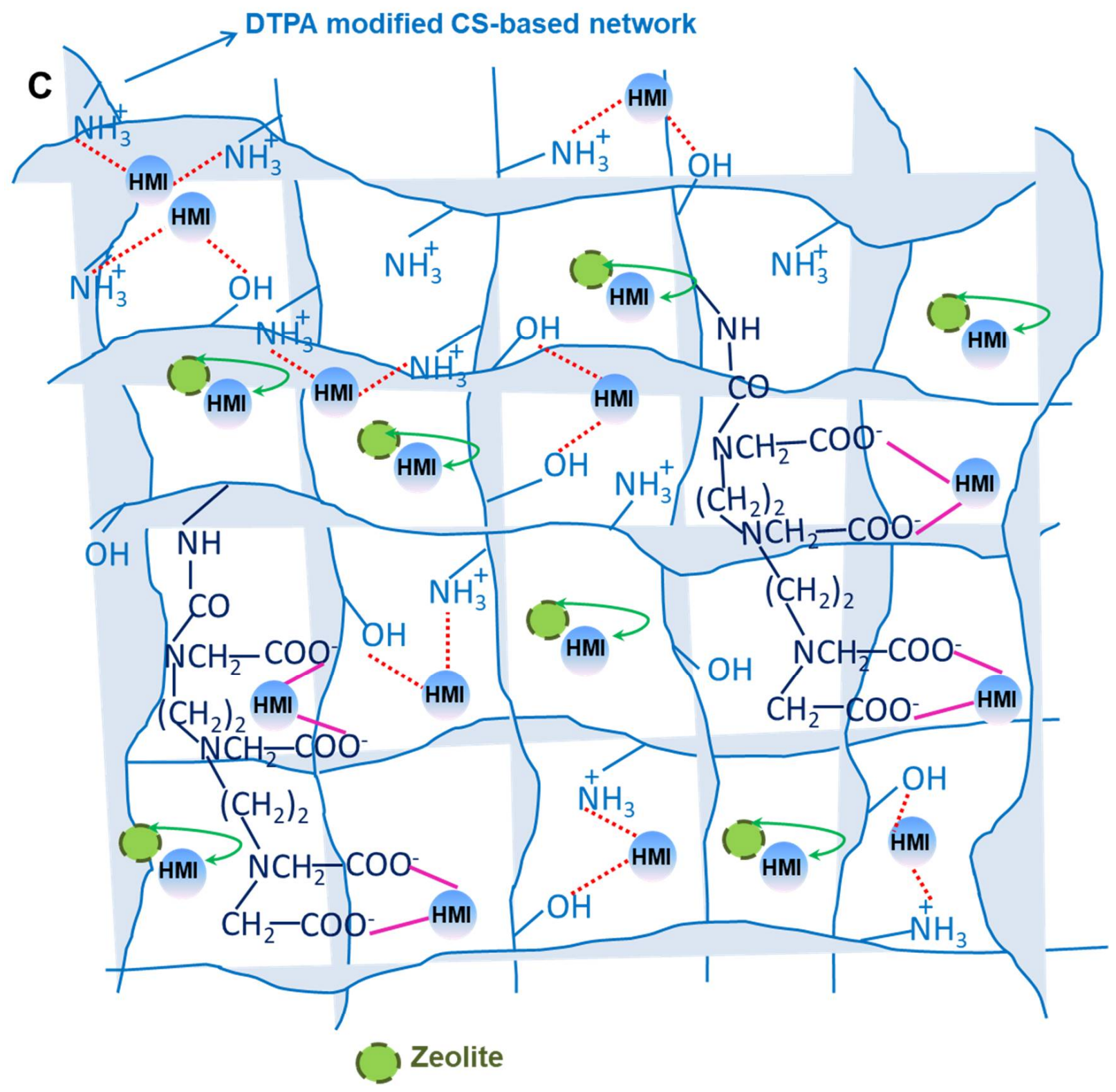

HMI Heavy metal ions

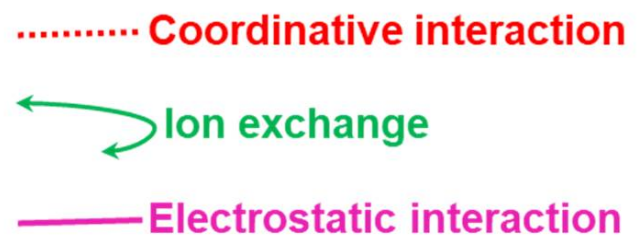

Figure 9. A schematic representation of the possible interactions between HMIs and the functional groups of each composite sponge: (A) CSZ sorbent; (B) CSZ-EDTA sorbent; and (C) CSZ-DTPA sorbent.

Table 1 summarizes the experimental data obtained on HMIs removal from ternary $(\mathrm{A}, \mathrm{B})$ and binary mixtures $(\mathrm{C}, \mathrm{D})$ using unmodified CSZ sorbent, EDTA-functionalized CSZ sorbent and DTPA-functionalized CSZ sorbent after the first and the fifth cycles of sorption. 

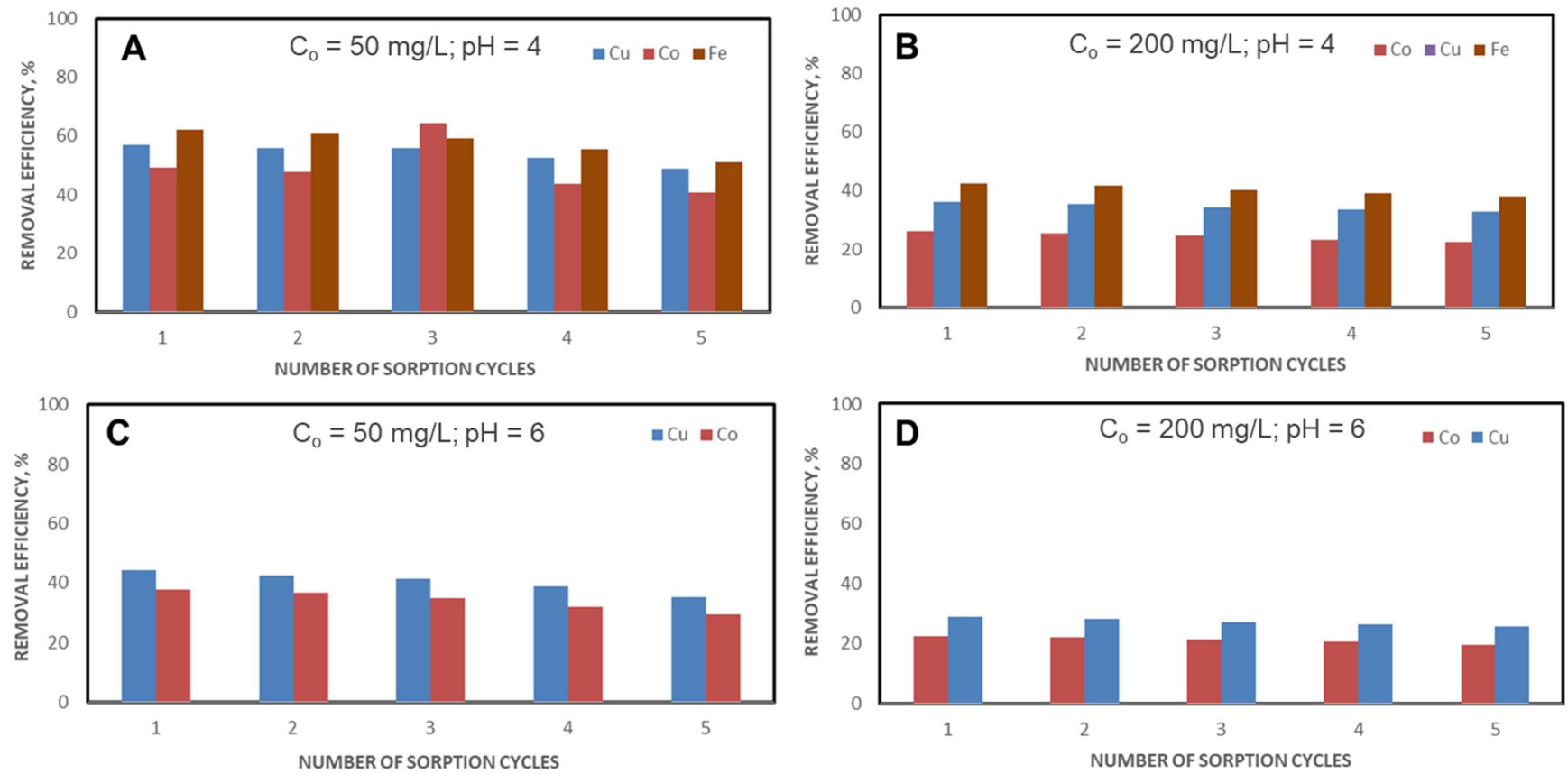

Figure 10. Influence of successive sorption/desorption cycles on HMIs removal from ternary (A,B) or binary mixtures (C,D) using unmodified CSZ sorbent. (A) $\mathrm{C}_{\mathrm{O}}=50 \mathrm{mg} / \mathrm{L} ; \mathrm{pH}=4 ;(\mathbf{B}) \mathrm{C}_{\mathrm{o}}=200 \mathrm{mg} / \mathrm{L} ; \mathrm{pH}=4 ;(\mathbf{C}) \mathrm{C}_{\mathrm{o}}=50 \mathrm{mg} / \mathrm{L} ; \mathrm{pH}=6$; (D) $\mathrm{C}_{\mathrm{o}}=200 \mathrm{mg} / \mathrm{L} ; \mathrm{pH}=6$.
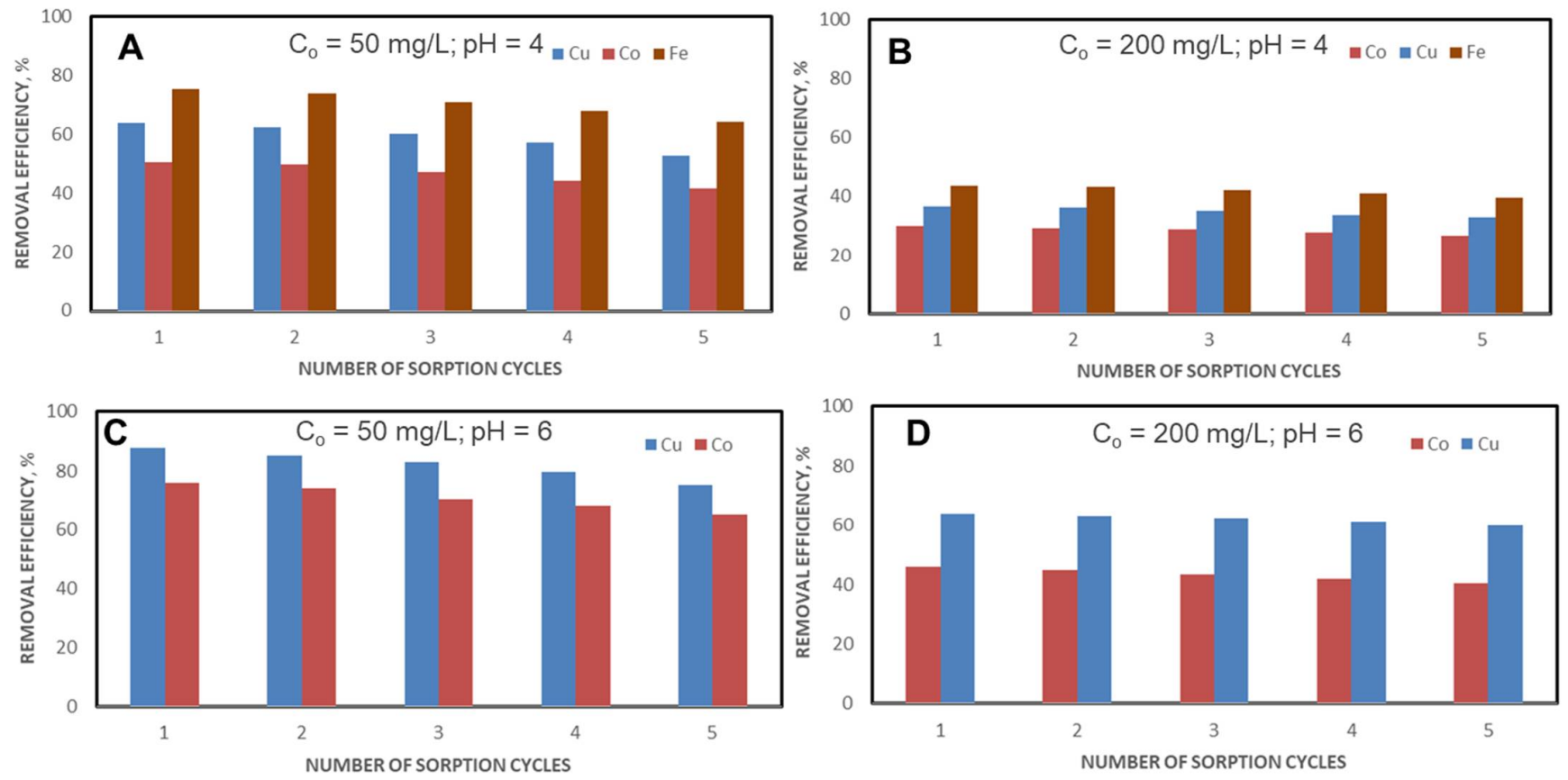

Figure 11. Influence of successive sorption/desorption cycles on HMIs removal from ternary (A,B) or binary mixtures (C,D) using EDTA-functionalized CSZ sorbent. (A) $\mathrm{C}_{\mathrm{o}}=50 \mathrm{mg} / \mathrm{L} ; \mathrm{pH}=4 ;(\mathbf{B}) \mathrm{C}_{\mathrm{o}}=200 \mathrm{mg} / \mathrm{L} ; \mathrm{pH}=4 ;(\mathbf{C}) \mathrm{C}_{\mathrm{o}}=50 \mathrm{mg} / \mathrm{L} ; \mathrm{pH}=6$; (D) $\mathrm{C}_{\mathrm{o}}=200 \mathrm{mg} / \mathrm{L} ; \mathrm{pH}=6$.

Analyzing the removal efficiency $(R E)$ values, it should be pointed out that better results were obtained when an initial HMI concentration of $50 \mathrm{mg} / \mathrm{L}$ and EDTA- or DTPAfunctionalized sorbents were used (Figures 10-12 and Table 1). Thus, at $\mathrm{pH}=4$, in the case of the unmodified CSZ sorbent, the percentage of $\mathrm{Cu}(\mathrm{II})$ ions retained decreased by $17.69 \%$ at the initial HMI concentration of $50 \mathrm{mg} / \mathrm{L}$ (Figure 10A) and by $9.41 \%$ for an initial HMI concentration of $200 \mathrm{mg} / \mathrm{L}$ (Figure 10B). However, for the unmodified CSZ sorbent, 
after the first cycle of sorption, removal efficiencies of only $57.32 \%, 49.38 \%$ and $62.16 \%$ were achieved for $\mathrm{Cu}(\mathrm{II}), \mathrm{Co}(\mathrm{II})$ and $\mathrm{Fe}(\mathrm{III})$ ions at an initial HMI concentration of $50 \mathrm{mg} / \mathrm{L}$ and $\mathrm{pH}$ of 4 (Figure 10A and Table 1). When the concentration increased to $200 \mathrm{mg} / \mathrm{L}$, the removal efficiency values for this sorbent drastically decreased to about $36.33 \%$ for $\mathrm{Cu}$ (II) ions, $26.48 \%$ for $\mathrm{Co}$ (II) ions and $42.63 \%$ for $\mathrm{Fe}$ (III) ions (Figure 10B and Table 1 ). A lower removal efficiency was also observed for the control sorbent (unmodified CSZ sample) even at $\mathrm{pH} 6$, irrespective of the initial HMI concentration (Figure 10C,D, and Table 1). By contrast, as Figures 11 and 12 and Table 1 show, the removal efficiency values of HMIs with EDTA- or DTPA-functionalized composite sorbents significantly increased compared to unmodified CSZ sorbents. In the ternary system, at an initial HMI concentration of $50 \mathrm{mg} / \mathrm{L}$ and $\mathrm{pH} 4$, the removal efficiency was about $64.14 \%$ for $\mathrm{Cu}(\mathrm{II})$ ions, $50.88 \%$ for $\mathrm{Co}(\mathrm{II})$ ions and $75.32 \% \mathrm{Fe}(\mathrm{III})$ ions when CSZ-EDTA sorbents were used (Figure 11A and Table 1). In the case of CSZ-DTPA sorbents, almost complete removal was observed for $\mathrm{Cu}(\mathrm{II})$ ions $(96.04 \%)$ and $\mathrm{Fe}(\mathrm{III})$ ions (98.26\%) (Figure 12A and Table 1). By raising the initial HMI concentration to $200 \mathrm{mg} / \mathrm{L}$ (Figures 11B and 12B and Table 1), the values of the removal efficiency of the $\mathrm{Cu}$ (II), $\mathrm{Co}$ (II) and $\mathrm{Fe}(\mathrm{III})$ ions were slightly diminished, as expected. In the binary system, at an initial HMI concentration of $50 \mathrm{mg} / \mathrm{L}$ and $\mathrm{pH} 6$, the removal efficiency with CSZ-EDTA sorbent was about $87.54 \%$ for $\mathrm{Cu}(\mathrm{II})$ ions and $75.94 \%$ for Co(II) ions (Figure 11C and Table 1), while with CSZ-DTPA sorbent the removal efficiency was around $96.84 \%$ for $\mathrm{Cu}(\mathrm{II})$ ions and $88.12 \%$ for $\mathrm{Co}(\mathrm{II})$ ions (Figure $12 \mathrm{C}$ and Table 1). At a higher initial HMI concentration $(200 \mathrm{mg} / \mathrm{L})$ and $\mathrm{pH} 6, \mathrm{Cu}$ (II) ions were preferentially desorbed with removal efficiencies of $63.68 \%$ and $85.27 \%$ by CSZ-EDTA sorbent (Figure 11D and Table 1) and CSZ-DTPA sorbent, respectively (Figure 12D and Table 1).
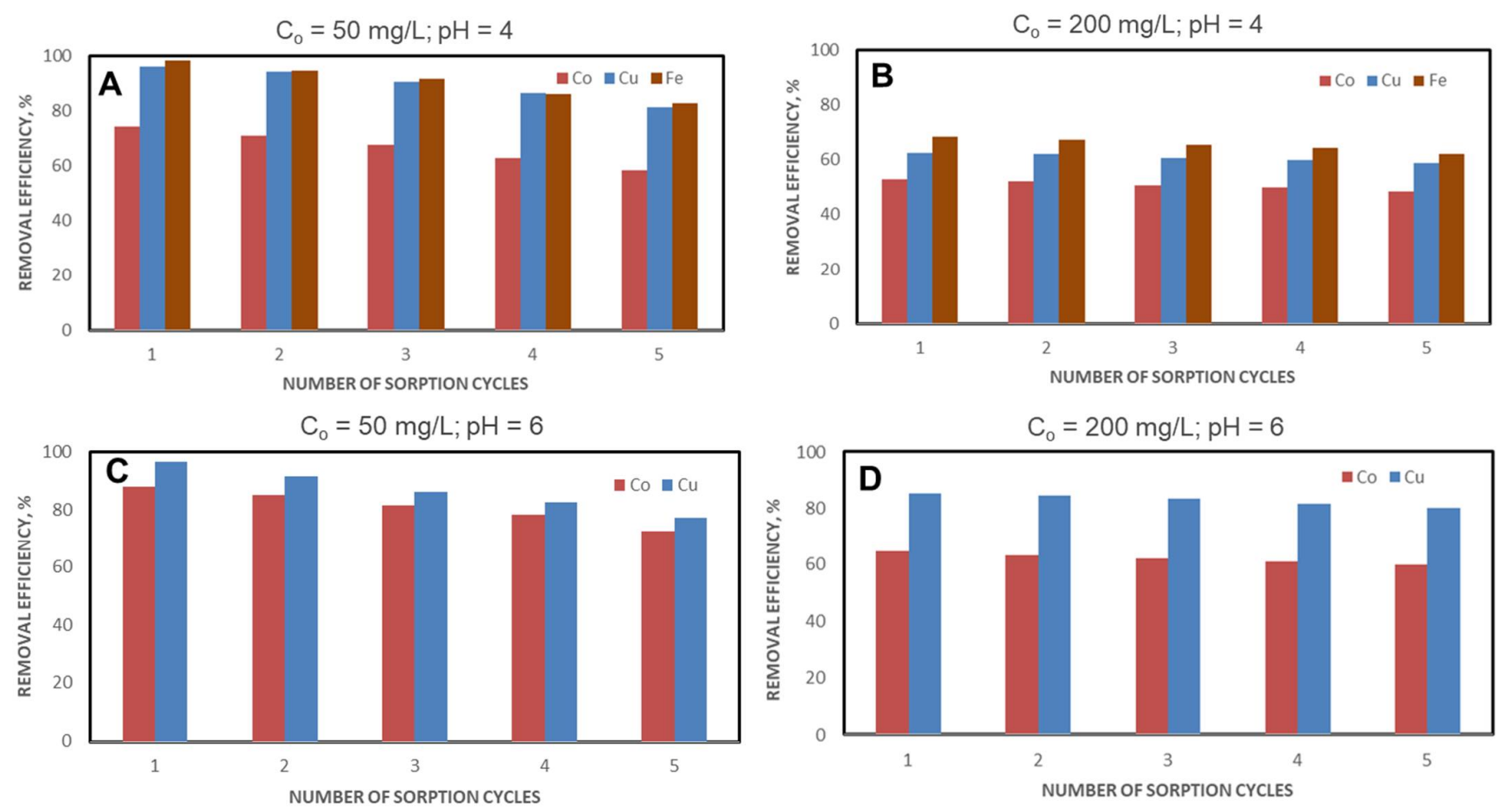

Figure 12. Influence of successive sorption/desorption cycles on HMIs removal from ternary (A,B) or binary mixtures (C,D) using DTPA-functionalized CSZ sorbent. (A) $\mathrm{C}_{\mathrm{o}}=50 \mathrm{mg} / \mathrm{L} ; \mathrm{pH}=4 ;(\mathbf{B}) \mathrm{C}_{\mathrm{o}}=200 \mathrm{mg} / \mathrm{L} ; \mathrm{pH}=4 ;(\mathbf{C}) \mathrm{C}_{\mathrm{o}}=50 \mathrm{mg} / \mathrm{L} ; \mathrm{pH}=6$; (D) $\mathrm{C}_{\mathrm{o}}=200 \mathrm{mg} / \mathrm{L} ; \mathrm{pH}=6$. 
Table 1. The removal efficiencies $(R E, \%)$ of the composite sponges after the first and the fifth cycles of sorption.

\begin{tabular}{|c|c|c|c|c|c|c|}
\hline \multirow{3}{*}{ Sorbents/pH } & \multicolumn{6}{|c|}{ Removal Efficiency $(R E, \%)$ after the First Cycle of Sorption } \\
\hline & \multicolumn{3}{|c|}{$\mathrm{C}_{0}=50 \mathrm{mg} / \mathrm{L}$} & \multicolumn{3}{|c|}{$\mathrm{C}_{0}=200 \mathrm{mg} / \mathrm{L}$} \\
\hline & $\mathrm{Cu}$ & Co & $\mathrm{Fe}$ & $\mathrm{Cu}$ & Co & Fe \\
\hline $\mathrm{CSZ} / \mathrm{pH} 4$ & 57.32 & 49.38 & 62.16 & 36.33 & 26.48 & 42.63 \\
\hline CSZ-EDTA/pH 4 & 64.14 & 50.88 & 75.32 & 36.79 & 30.08 & 43.83 \\
\hline CSZ-DTPA/pH 4 & 96.04 & 74.18 & 98.26 & 62.69 & 52.82 & 68.53 \\
\hline $\mathrm{CSZ} / \mathrm{pH} 6$ & 44.08 & 37.77 & - & 28.71 & 22.44 & - \\
\hline CSZ-EDTA/pH 6 & 87.54 & 75.94 & - & 63.68 & 45.72 & - \\
\hline CSZ-DTPA/pH 6 & 96.84 & 88.12 & - & 85.27 & 64.58 & - \\
\hline \multirow{3}{*}{ Sorbents/pH } & \multicolumn{6}{|c|}{ Removal Efficiency $(R E, \%)$ after the Fifth Cycle of Sorption } \\
\hline & \multicolumn{3}{|c|}{$C_{0}=50 \mathrm{mg} / \mathrm{L}$} & \multicolumn{3}{|c|}{$\mathrm{C}_{0}=200 \mathrm{mg} / \mathrm{L}$} \\
\hline & $\mathrm{Cu}$ & Co & $\mathrm{Fe}$ & $\mathrm{Cu}$ & Co & $\mathrm{Fe}$ \\
\hline $\mathrm{CSZ} / \mathrm{pH} 4$ & 49.15 & 41.02 & 51.26 & 32.91 & 22.64 & 38.22 \\
\hline CSZ-EDTA/pH 4 & 52.86 & 41.92 & 64.34 & 32.87 & 26.72 & 39.72 \\
\hline CSZ-DTPA/pH 4 & 81.26 & 58.36 & 82.72 & 58.82 & 48.66 & 62.26 \\
\hline $\mathrm{CSZ} / \mathrm{pH} 6$ & 35.04 & 29.42 & - & 25.62 & 19.42 & - \\
\hline CSZ-EDTA/pH 6 & 75.26 & 65.24 & - & 59.83 & 40.31 & - \\
\hline CSZ-DTPA/pH 6 & 77.44 & 72.66 & - & 80.13 & 59.83 & - \\
\hline
\end{tabular}

Nevertheless, as can be seen from Figures 10-12 and Table 1, there was a high regeneration capacity, i.e., the removal efficiency values remained almost unchanged for all CS-based composite sorbents even after the fifth cycle of sorption/desorption, indicating their remarkable chemical stability under HMI leaching and sorbent regeneration conditions.

The values of the sorption data obtained in this study for CSZ, CSZ-EDTA and CSZDTPA sponges were compared with those reported for other sorbents in Table 2.

Table 2. Comparative sorption data for removal of HMIs from multicomponent aqueous mixtures by various sorbents.

\begin{tabular}{|c|c|c|c|c|c|c|c|}
\hline Sorbents & $\begin{array}{c}\text { Type of Multicomponent } \\
\text { Mixture }\end{array}$ & HMI & $\mathrm{pH}$ & $\mathrm{C}_{0}, \mathrm{mg} / \mathrm{L}$ & $\begin{array}{l}\text { Sorbent Dose, } \\
\mathrm{g} / \mathrm{L}\end{array}$ & $\mathrm{q}_{\mathrm{e}}, \mathrm{mg} / \mathrm{g}$ & Refs. \\
\hline $\begin{array}{l}\text { Granular activated } \\
\text { carbon (GAC) }\end{array}$ & Ternary & $\begin{array}{l}\mathrm{Al}(\mathrm{III}) \\
\mathrm{Fe}(\mathrm{III}) \\
\mathrm{Mn}(\mathrm{II})\end{array}$ & 5 & $26-122$ & 2 & $\begin{array}{c}106.5 \\
14.8 \\
7.6\end{array}$ & [34] \\
\hline Amberlite IR-120H & Ternary & $\begin{array}{c}\mathrm{Al}(\mathrm{III}) \\
\mathrm{Fe}(\mathrm{III}) \\
\mathrm{Mn}(\mathrm{II})\end{array}$ & 5 & $26-122$ & 2 & $\begin{array}{c}108.7 \\
15.6 \\
8.7\end{array}$ & {$[34]$} \\
\hline Activate carbon & Ternary & $\begin{array}{l}\mathrm{Cu}(\mathrm{II}) \\
\mathrm{Ni}(\mathrm{II}) \\
\mathrm{Zn}(\mathrm{II})\end{array}$ & 5.5 & $10-100$ & 2.5 & $\begin{array}{l}18.6 \\
16.1 \\
12.1\end{array}$ & {$[35]$} \\
\hline \multirow{4}{*}{ CS-coated perlite beads } & Binary & $\begin{array}{l}\mathrm{Cu}(\mathrm{II}) \\
\mathrm{Ni}(\mathrm{II})\end{array}$ & \multirow{4}{*}{5} & \multirow{4}{*}{ 50-200 } & \multirow{4}{*}{2.5} & $\begin{array}{c}147.0 \\
38.9\end{array}$ & \multirow{4}{*}{ [36] } \\
\hline & Binary & $\begin{array}{l}\mathrm{Cu}(\mathrm{II}) \\
\mathrm{Co}(\mathrm{II})\end{array}$ & & & & $\begin{array}{c}156.2 \\
39.8\end{array}$ & \\
\hline & Binary & $\begin{array}{l}\mathrm{Ni}(\mathrm{II}) \\
\mathrm{Co}(\mathrm{II})\end{array}$ & & & & $\begin{array}{l}56.1 \\
66.6\end{array}$ & \\
\hline & Ternary & $\begin{array}{l}\mathrm{Cu}(\mathrm{II}) \\
\mathrm{Co}(\mathrm{II}) \\
\mathrm{Ni}(\mathrm{II})\end{array}$ & & & & $\begin{array}{c}128.2 \\
35.2 \\
30.4\end{array}$ & \\
\hline
\end{tabular}


Table 2. Cont.

\begin{tabular}{|c|c|c|c|c|c|c|c|}
\hline Sorbents & $\begin{array}{c}\text { Type of Multicomponent } \\
\text { Mixture }\end{array}$ & HMI & $\mathrm{pH}$ & $\mathrm{C}_{0}, \mathrm{mg} / \mathrm{L}$ & $\begin{array}{l}\text { Sorbent Dose, } \\
\mathrm{g} / \mathrm{L}\end{array}$ & $\mathrm{q}_{\mathrm{e}}, \mathrm{mg} / \mathrm{g}$ & Refs. \\
\hline \multirow{3}{*}{$\begin{array}{c}\mathrm{Cu}^{2+} \text {-ion-imprinted } \\
\text { polymer }\end{array}$} & Binary & $\begin{array}{l}\mathrm{Cu}(\mathrm{II}) \\
\mathrm{Ni}(\mathrm{II})\end{array}$ & \multirow{3}{*}{6} & \multirow{3}{*}{$30-90$} & \multirow{3}{*}{3} & $\begin{array}{l}53.1 \\
7.7\end{array}$ & \multirow{3}{*}{ [37] } \\
\hline & Binary & $\begin{array}{l}\mathrm{Cu}(\mathrm{II}) \\
\mathrm{Zn}(\mathrm{II})\end{array}$ & & & & $\begin{array}{l}40.2 \\
3.3\end{array}$ & \\
\hline & Binary & $\begin{array}{l}\mathrm{Cu}(\mathrm{II}) \\
\mathrm{Pb}(\mathrm{II})\end{array}$ & & & & $\begin{array}{c}38.4 \\
128.1\end{array}$ & \\
\hline SBA-15 mesoporous silica & Quaternary & $\begin{array}{l}\mathrm{Cu}(\mathrm{II}) \\
\mathrm{Ni}(\mathrm{II}) \\
\mathrm{Co}(\mathrm{II}) \\
\mathrm{Zn}(\mathrm{II})\end{array}$ & 4.8 & & 1 & $\begin{array}{l}8.2 \\
7.6 \\
4.7 \\
5.5\end{array}$ & [38] \\
\hline $\begin{array}{l}\text { N-propylsalicylaldimino- } \\
\text { functionalized SBA-15 } \\
\text { mesoporous silica }\end{array}$ & Quaternary & $\begin{array}{l}\mathrm{Cu}(\mathrm{II}) \\
\mathrm{Ni}(\mathrm{II}) \\
\mathrm{Co}(\mathrm{II}) \\
\mathrm{Zn}(\mathrm{II})\end{array}$ & 4.8 & & 1 & $\begin{array}{l}44 \\
3.5 \\
2.9 \\
2.6\end{array}$ & [38] \\
\hline $\begin{array}{l}\text { Acid-activated Romanian } \\
\text { zeolite }\end{array}$ & Five-component & $\begin{array}{l}\mathrm{Cu}(\mathrm{II}) \\
\mathrm{Fe}(\mathrm{III}) \\
\mathrm{Ni}(\mathrm{II}) \\
\mathrm{Zn}(\mathrm{II}) \\
\mathrm{Cr}(\mathrm{III})\end{array}$ & $\begin{array}{c}5 \\
4 \\
4.5 \\
5 \\
3.5\end{array}$ & 50-1000 & 3.5 & $\begin{array}{c}9.7 \\
7.3 \\
2.2 \\
2.2 \\
0.12\end{array}$ & [11] \\
\hline $\begin{array}{l}\text { CS/acid-activated } \\
\text { Romanian zeolite } \\
\text { composite cryogels }\end{array}$ & Five-component & $\begin{array}{l}\mathrm{Cu}(\mathrm{II}) \\
\mathrm{Fe}(\mathrm{III}) \\
\mathrm{Ni}(\mathrm{II}) \\
\mathrm{Zn} \text { (II) } \\
\mathrm{Cr}(\mathrm{III})\end{array}$ & $\begin{array}{c}5 \\
4 \\
4.5 \\
5 \\
3.5\end{array}$ & 50-1000 & 3.5 & $\begin{array}{c}61.1 \\
18.6 \\
12.2 \\
53.4 \\
0.8\end{array}$ & [11] \\
\hline \multirow{4}{*}{ CSZ } & Binary & $\begin{array}{l}\mathrm{Cu}(\mathrm{II}) \\
\mathrm{Fe}(\mathrm{III})\end{array}$ & 4 & 200 & 0.4 & $\begin{array}{l}113.3 \\
161.6\end{array}$ & \multirow{13}{*}{$\begin{array}{l}\text { This } \\
\text { study }\end{array}$} \\
\hline & Binary & $\begin{array}{l}\mathrm{Cu}(\mathrm{II}) \\
\mathrm{Co}(\mathrm{II})\end{array}$ & 4 & 200 & 0.4 & $\begin{array}{c}107.8 \\
80.3\end{array}$ & \\
\hline & Binary & $\begin{array}{l}\mathrm{Co}(\mathrm{II}) \\
\mathrm{Fe}(\mathrm{III})\end{array}$ & 4 & 200 & 0.4 & $\begin{array}{c}82.8 \\
157.5\end{array}$ & \\
\hline & Binary & $\begin{array}{l}\mathrm{Cu}(\mathrm{II}) \\
\mathrm{Co}(\mathrm{II})\end{array}$ & 6 & 200 & 0.4 & $\begin{array}{l}188.3 \\
115.3\end{array}$ & \\
\hline \multirow{4}{*}{ CSZ-EDTA } & Binary & $\begin{array}{l}\mathrm{Cu}(\mathrm{II}) \\
\mathrm{Fe}(\mathrm{III})\end{array}$ & 4 & 200 & 0.4 & $\begin{array}{l}135.3 \\
189.6\end{array}$ & \\
\hline & Binary & $\begin{array}{l}\mathrm{Cu}(\mathrm{II}) \\
\mathrm{Co}(\mathrm{II})\end{array}$ & 4 & 200 & 0.4 & $\begin{array}{l}130.7 \\
110.6\end{array}$ & \\
\hline & Binary & $\begin{array}{l}\mathrm{Co}(\mathrm{II}) \\
\mathrm{Fe}(\mathrm{III})\end{array}$ & 4 & 200 & 0.4 & $\begin{array}{l}112.2 \\
180.2 \\
\end{array}$ & \\
\hline & Binary & $\begin{array}{l}\mathrm{Cu}(\mathrm{II}) \\
\mathrm{Co}(\mathrm{II})\end{array}$ & 6 & 200 & 0.4 & $\begin{array}{l}190.64 \\
118.0\end{array}$ & \\
\hline \multirow{4}{*}{ CSZ-DTPA } & Binary & $\begin{array}{l}\mathrm{Cu}(\mathrm{II}) \\
\mathrm{Fe}(\mathrm{III})\end{array}$ & 4 & 200 & 0.4 & $\begin{array}{l}145.4 \\
206.7\end{array}$ & \\
\hline & Binary & $\begin{array}{l}\mathrm{Cu}(\mathrm{II}) \\
\mathrm{Co}(\mathrm{II})\end{array}$ & 4 & 200 & 0.4 & $\begin{array}{l}141.9 \\
129.1\end{array}$ & \\
\hline & Binary & $\begin{array}{l}\mathrm{Co}(\mathrm{II}) \\
\mathrm{Fe}(\mathrm{III})\end{array}$ & 4 & 200 & 0.4 & $\begin{array}{l}133.8 \\
203.7\end{array}$ & \\
\hline & Binary & $\begin{array}{l}\mathrm{Cu}(\mathrm{II}) \\
\mathrm{Co}(\mathrm{II})\end{array}$ & 6 & 200 & 0.4 & $\begin{array}{l}218.0 \\
130.4\end{array}$ & \\
\hline CSZ & Ternary & $\begin{array}{l}\mathrm{Cu}(\mathrm{II}) \\
\mathrm{Co}(\mathrm{II}) \\
\mathrm{Fe}(\mathrm{III})\end{array}$ & 4 & 200 & 0.4 & $\begin{array}{c}105.7 \\
74.5 \\
148.6\end{array}$ & \\
\hline
\end{tabular}


Table 2. Cont.

\begin{tabular}{|c|c|c|c|c|c|c|c|}
\hline Sorbents & $\begin{array}{c}\text { Type of Multicomponent } \\
\text { Mixture }\end{array}$ & HMI & $\mathrm{pH}$ & $\mathrm{C}_{0}, \mathrm{mg} / \mathrm{L}$ & $\begin{array}{c}\text { Sorbent Dose, } \\
\mathrm{g} / \mathrm{L}\end{array}$ & $q_{e}, m g / g$ & Refs. \\
\hline CSZ-EDTA & Ternary & $\begin{array}{l}\mathrm{Cu}(\mathrm{II}) \\
\mathrm{Co}(\mathrm{II}) \\
\mathrm{Fe}(\mathrm{III})\end{array}$ & 4 & 200 & 0.4 & $\begin{array}{c}128.2 \\
91.5 \\
177.7\end{array}$ & \multirow{2}{*}{$\begin{array}{l}\text { This } \\
\text { study }\end{array}$} \\
\hline CSZ-DTPA & Ternary & $\begin{array}{l}\mathrm{Cu}(\mathrm{II}) \\
\mathrm{Co}(\mathrm{II}) \\
\mathrm{Fe}(\mathrm{III})\end{array}$ & 4 & 200 & 0.4 & $\begin{array}{l}138.6 \\
103.5 \\
188.0\end{array}$ & \\
\hline
\end{tabular}

Although all the sorbents included in Table 2 can be exploited for the removal of HMIs from multicomponent aqueous mixtures, it is important to point out that the choice of the best sorbent material should rely on various aspects, including the composition of the aqueous mixtures, the $\mathrm{pH}$ of the solution, the initial concentration of the HMIs and the sorbent dose. The values of qe for CSZ, CSZ-EDTA and CSZ-DTPA composite sorbents were comparable and even higher than those previously reported for other sorbents, supporting their great potential for application in the treatment of wastewaters containing HMIs.

\section{Conclusions}

The sorption performances of ethylenediaminetetraacetic acid (EDTA)- and diethylenetriaminepentaacetic acid (DTPA)-functionalized CS composite sponges, entrapping a natural zeolite, towards the removal of $\mathrm{Cu}(\mathrm{II}), \mathrm{Co}$ (II) and $\mathrm{Fe}(\mathrm{III})$ ions from binary or ternary aqueous mixtures was evaluated in depth in this work in comparison to those of unmodified CS-based sorbents. The effect of the initial HMI concentration and $\mathrm{pH}$ on the sorption features is well-established. All CS-based composite sorbents in acidic medium $(\mathrm{pH}=4)$ exhibited a high affinity for $\mathrm{Fe}(\mathrm{III})$ ions when they were in a mixture with $\mathrm{Cu}$ (II) or $\mathrm{Co}$ (II) ions. The experimental $\mathrm{q}_{\mathrm{e}}$ values for removal of $\mathrm{Fe}(\mathrm{III})$ ions from their mixture with $\mathrm{Cu}$ (II) ions by CSZ, CSZ-EDTA and CSZ-DTPA sorbents were $161.60 \mathrm{mg} / \mathrm{g}, 189.61 \mathrm{mg} / \mathrm{g}$ and $206.65 \mathrm{mg} / \mathrm{g}$, respectively. The $\mathrm{q}_{\mathrm{e}}$ values for Fe(III) ion sorption slightly decreased when they were adsorbed from the binary system with $\mathrm{Co}(\mathrm{II})$. Thus, the amounts of Fe(III) retained by CS-based composite sorbents ranged from $157.56 \mathrm{mg} / \mathrm{g}$ to $203.75 \mathrm{mg} / \mathrm{g}$. The HMI desorption and sorbent recycling studies demonstrated that better results are obtained when an initial HMI concentration of $50 \mathrm{mg} / \mathrm{L}$ and EDTA- or DTPA-functionalized sorbents are used. In the ternary system, at an initial HMI concentration of $50 \mathrm{mg} / \mathrm{L}$ and $\mathrm{pH} 4$, the removal efficiency was about $64.14 \%$ for $\mathrm{Cu}$ (II) ions, $50.88 \%$ for $\mathrm{Co}$ (II) ions and $75.32 \%$ for $\mathrm{Fe}(\mathrm{III})$ ions when CSZ-EDTA sorbents were used. In the case of CSZ-DTPA sorbents, an almost complete removal was observed for $\mathrm{Cu}(\mathrm{II})$ ions (96.04\%) and $\mathrm{Fe}(\mathrm{III})$ ions $(98.26 \%$ ). Moreover, a high regeneration capacity was observed for all CS-based composite sorbents even after the fifth cycle of sorption/desorption, which clearly indicates their remarkable chemical stability and potential application in wastewater treatment. As real-life aqueous effluents are composed of more complex mixtures of contaminants than the investigated systems, ongoing experiments will be dedicated to evaluate their removal by the newly prepared composite sponge sorbents. In addition, the beads can be easily prepared and the next step is their testing under dynamic operation conditions.

\section{Materials and Methods}

\subsection{Materials}

Chitosan (CS) with a relative viscosity-average molecular weight of $342 \mathrm{kDa}$ and a deacetylation degree (DD) of $85 \%$ was purchased from Sigma-Aldrich. Glutaraldehyde (GA) solution at a concentration of $25 \%(\mathrm{w} / \mathrm{w})$ in $\mathrm{H}_{2} \mathrm{O}$ was used as cross-linker and was also acquired from Sigma-Aldrich. The zeolite fraction, of sizes in the $0.032-0.050 \mathrm{~mm}$ range, was obtained from the volcanic tuffs cropping out in the Macicas area (Cluj County, Romania) and was used as inorganic filler within the CS matrix. 4,4'-Ethylenebis(2,6morpholinedione) (EDTA dianhydride (EDTAD)) and N,N-Bis [2-(2,6-dioxomorpholino) 
ethyl]glycine (DTPA dianhydride (DTPAD)), provided by Sigma-Aldrich, were used as received, without any further purification.

$\mathrm{CoCl}_{2} \cdot 6 \mathrm{H}_{2} \mathrm{O}, \mathrm{CuSO}_{4} \cdot 5 \mathrm{H}_{2} \mathrm{O}$ and $\mathrm{Fe}\left(\mathrm{NO}_{3}\right)_{3} \cdot 9 \mathrm{H}_{2} \mathrm{O}$ were used as sources of HMIs and were purchased from Sigma-Aldrich. Hydrochloric acid, sodium hydroxide, acetic acid and methanol of the highest commercial purity, provided by Chemical Company, Romania, were used as received.

\subsection{Methods}

\subsubsection{Preparation and Functionalization of CSZ Composite Sponges}

Chemically cross-linked CS-based sorbents, formed into beads, were prepared in the presence of a natural zeolite using the ice-segregation technique, which consisted of a cryogenic process with three stages: freezing in liquid nitrogen, storage in the frozen state for a certain time, and defrosting, following a procedure previously reported [32,39] with some modifications. Thus, $2 \mathrm{~g}$ of CS (324 kDa, 85\% DD) was dissolved in $100 \mathrm{~mL}$ of $1 \mathrm{wt} . \%$ acetic acid aqueous solution. Afterwards, $0.75 \mathrm{~g}$ of natural zeolite was added under vigorous stirring. Finally, $3.2 \mathrm{~mL}$ of GA ( $5 \mathrm{wt} . \%$ ) was added dropwise over $30 \mathrm{~min}$. The homogeneous dispersion obtained after $1 \mathrm{~h}$ of vigorous stirring was added drop-bydrop, with an Eppendorf pipette, into liquid nitrogen (LN). The frozen droplets were separated from the LN and immediately transferred to an Arctiko Freezer at $-18{ }^{\circ} \mathrm{C}$ to ensure the complete cross-linking of CS by GA. After $24 \mathrm{~h}$, the CS beads were thawed at room temperature for $1 \mathrm{~h}$ and washed several times with MilliQ water. The CSZ beads were freeze-dried in a LABCONCO FreeZone apparatus for $48 \mathrm{~h}$, at $-50{ }^{\circ} \mathrm{C}$ and $0.04 \mathrm{mbar}$. Ethylenediaminetetraacetic acid (EDTA) or diethylenetriaminepentaacetic acid (DTPA) ligand moieties were generated onto the CSZ composite sponges by reaction with EDTAD or DTPAD in a 1:1 $v / v$ acetic acid-methanol mixture, following a procedure previously reported [40].

\subsubsection{Morphology and Elemental Surface Composition}

The cross-sectional microstructure of the composite sponges was observed with a Quanta 200-FEI-type environmental scanning electron microscope (ESEM) at $20 \mathrm{kV}$ in low vacuum mode. An energy dispersive X-ray (EDX) detector was used to map the elements and to estimate their ratio and distribution within the CSZ-based composites.

\subsubsection{Sorption Studies}

The sorption performance of the CSZ-based composite sorbents was examined under competitive conditions, i.e., using a two- or three-component mixture of $\mathrm{Cu}(\mathrm{II}), \mathrm{Co}$ (II) and Fe(III) ions in batch mode. The effect of the initial HMI concentration $(50 \mathrm{mg} / \mathrm{L}$ and $200 \mathrm{mg} / \mathrm{L}$ ), as well as the influence of the solution $\mathrm{pH}$ (4 or 6), was investigated, while the other parameters were kept constant. The solutions were equilibrated for $24 \mathrm{~h}$ at $200 \mathrm{rpm}$. The final HMI concentrations were determined by flame atomic absorption spectrometry (FAAS) using a high-resolution ContrAA 300 Analytik Jena spectrometer equipped with a xenon lamp as a continuum radiation source. During experiment an aspiration rate of

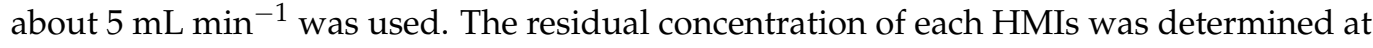
the characteristic maximum wavelengths of $240 \mathrm{~nm}$ for $\mathrm{Co}(\mathrm{II})$ ions, $324 \mathrm{~nm}$ for $\mathrm{Cu}$ (II) ions and $248 \mathrm{~nm}$ for Fe(III) ions, respectively. The amount of HMI adsorbed at equilibrium ( $\mathrm{q}_{\mathrm{e}}$, $\mathrm{mg} \mathrm{g}^{-1}$ ) on all CSZ-based sorbents was calculated as:

$$
q_{e}=\frac{\left(C_{0}-C_{e}\right) \times V}{m}
$$

where $C_{0}$-initial HMI concentration, $\mathrm{mg} \mathrm{L}^{-1} ; C_{e}$-concentration of the HMIs in aqueous solution at equilibrium, $\mathrm{mg} \mathrm{L}^{-1} ; V$-volume of aqueous solution, $\mathrm{L}$; and $m$-sorbent dose, $g$. 


\subsubsection{Desorption and Reusability Experiments}

In order to investigate the sorbent reusability, the HMIs loaded onto CSZ-based sorbents were eluted with $0.1 \mathrm{M} \mathrm{HCl}$ aqueous solution. Then, the CSZ-based sorbents were washed several times with distilled water and were regenerated with $0.1 \mathrm{M} \mathrm{NaOH}$ aqueous solution. After this treatment, the sorbents were reused in another cycle of sorption. The residual concentration of each HMI was determined by FAAS.

The efficiency of HMI removal (RE, \%) from aqueous solution on all CSZ-based sorbents was calculated as:

$$
R E(\%)=\frac{C_{0}-C_{e}}{C_{0}} \times 100
$$

where $C_{o}$ and $C_{e}$ have the same meanings as in Equation (1).

Author Contributions: Conceptualization, M.V.D.; methodology, M.V.D., D.H. and M.M.L.; validation, M.V.D., D.H. and M.M.L.; formal analysis, D.H. and M.M.L.; investigation, D.H. and M.M.L.; resources, M.V.D.; writing—original draft preparation, M.V.D. and M.M.L.; writing—review and editing, M.V.D.; project administration, M.V.D. All authors have read and agreed to the published version of the manuscript.

Funding: The Romanian Ministry of Research and Innovation (CCCDI-UEFISCDI) through TE 117/2018 and PN-III-P4-ID-PCE-2020-0296 projects are acknowledged for financial support.

Institutional Review Board Statement: Not applicable.

Informed Consent Statement: Not applicable.

Data Availability Statement: Not applicable.

Acknowledgments: The authors gratefully thank Maria Ignat and student Ancuta Tapalaga for the AAS measurements.

Conflicts of Interest: The authors declare no conflict of interest.

\section{References}

1. $\mathrm{Hu}, \mathrm{H}$. Human health and heavy metals exposure. In Life Support: The Environment and Human Health; McCally, M., Ed.; MIT Press: Cambridge, UK, 2002; Volume 4, pp. 1-12.

2. Dragan, E.S.; Dinu, M.V. Advances in porous chitosan-based composite hydrogels: Synthesis and applications. React. Funct. Polym. 2020, 146, 104372. [CrossRef]

3. Beyki, M.H.; Shemirani, F.; Shirkhodaie, M. Aqueous $\mathrm{Co}(\mathrm{II})$ adsorption using 8-hydroxyquinoline anchored- $\mathrm{Fe}_{2} \mathrm{O}_{3} @$ chitosan with Co(II) as imprinted ions. Int. J. Biol. Macromol. 2016, 87, 375-384. [CrossRef]

4. Abbaspour, N.; Hurrell, R.; Kelishadi, R. Review on iron and its importance for human health. J. Res. Med. Sci. 2014, 19, 164-174. [PubMed]

5. Guemiza, K.; Coudert, L.; Metahni, S.; Mercier, G.; Besner, S.; Blais, J.F. Treatment technologies used for the removal of As, $\mathrm{Cr}, \mathrm{Cu}$, PCP and/or PCDD/F from contaminated soil: A review. J. Hazard. Mater. 2017, 333, 194-214. [CrossRef]

6. Dragan, E.S.; Avram, E.; Dinu, M.V. Organic ion exchangers as beads. Synthesis, characterization and applications. Polym. Adv. Technol. 2006, 17, 571-578. [CrossRef]

7. Cao, D.Q.; Wang, X.; Wang, Q.H.; Fang, X.M.; Jin, J.Y.; Hao, X.D.; Iritani, E.; Katagiri, N. Removal of heavy metal ions by ultrafiltration with recovery of extracellular polymer substances from excess sludge. J. Membr. Sci. 2020, 606, 118103. [CrossRef]

8. Dragan, E.S.; Humelnicu, D.; Dinu, M.V. Design of porous strong base anion exchangers bearing N,N-dialkyl 2-hydroxyethyl ammonium groups with enhanced retention of $\mathrm{Cr}(\mathrm{VI})$ ions from aqueous solution. React. Funct. Polym. 2018, 124, 55-63. [CrossRef]

9. Liao, G.; Zhong, L.; Cheung, C.S.; Du, C.; Wu, J.; Du, W.; Zheng, H.; Gao, H. Direct synthesis of hypercrosslinked microporous poly(para-methoxystyrene) for removal of iron(III) ion from aqueous solution. Microporous Mesoporous Mater. 2020, 307, 110469. [CrossRef]

10. Dinu, M.V.; Dinu, I.A.; Lazar, M.M.; Dragan, E.S. Insights into the mechanism of $\mathrm{Cu}^{2+}$ binding onto chitosan-based cryogel composites: Equilibrium, kinetics and thermodynamics studies. Cell. Chem. Technol. 2018, 52, 181-192.

11. Humelnicu, D.; Dragan, E.S.; Ignat, M.; Dinu, M.V. A comparative study on $\mathrm{Cu}^{2+}, \mathrm{Zn}^{2+}, \mathrm{Ni}^{2+}, \mathrm{Fe}^{3+}$, and $\mathrm{Cr}^{3+}$ metal ions removal from industrial wastewaters by chitosan-based composite cryogels. Molecules 2020, 25, 2664. [CrossRef] [PubMed]

12. Beaugeard, V.; Muller, J.; Graillot, A.; Ding, X.; Robin, J.J.; Monge, S. Acidic polymeric sorbents for the removal of metallic pollution in water: A review. React. Funct. Polym. 2020, 152, 104599. [CrossRef] 
13. Zhang, H.; Xu, F.; Xue, J.; Chen, S.; Wang, J.; Yang, Y. Enhanced removal of heavy metal ions from aqueous solution using manganese dioxide-loaded biochar: Behavior and mechanism. Sci. Rep. 2020, 10, 6067. [CrossRef]

14. Ma, L.; Wang, Q.; Islam, S.M.; Liu, Y.; Ma, S.; Kanatzidis, M.G. Highly selective and efficient removal of heavy metals by layered double hydroxide intercalated with the $\mathrm{MoS}_{4}{ }^{2-}$ ion. J. Am. Chem. Soc. 2016, 138, 2858-2866. [CrossRef] [PubMed]

15. Hossein, M.I.; Haghighi, K. Removal of heavy metals from polluted solutions by zeolitic adsorbents: A review. Environ. Process. 2021, 8, 7-35.

16. Zorpas, A.A.; Pedreño, J.N.; Candel, M.B.A. Heavy metal treatment and removal using natural zeolites from sewage sludge, compost, and agricultural soils: A review. Arab. J. Geosci. 2021, 14, 1098. [CrossRef]

17. Tounsadi, H.; Khalidi, A.; Machrouhi, A.; Farnane, M.; Elmoubarki, R.; Elhalil, A.; Sadiq, M.; Barka, N. Highly efficient activated carbon from Glebionis coronaria L. biomass: Optimization of preparation conditions and heavy metals removal using experimental design approach. J. Environ. Chem. Eng. 2016, 4, 4549-4564. [CrossRef]

18. Ibrahim, B.A.; Kassem, O.A.; Alhebeshy, R. Utilization of carbon nanotubes in removal of heavy metals from wastewater: A review of the CNTs' potential and current challenges. Appl. Phys. A Mater. 2020, 126, 38.

19. Deng, J.; Li, X.; Wei, X.; Liu, Y.; Liang, J.; Song, B.; Shao, Y.; Huang, W. Hybrid silicate-hydrochar composite for highly efficient removal of heavy metal and antibiotics: Coadsorption and mechanism. Chem. Eng. J. 2020, 387, 124097. [CrossRef]

20. Guibal, E.; Vincent, T.; Navarro, R. Metal ion biosorption on chitosan for the synthesis of advanced materials. J. Mater. Sci. 2014, 49,5505-5518. [CrossRef]

21. Ghiorghita, C.A.; Borchert, K.B.L.; Vasiliu, A.L.; Zaharia, M.M.; Schwarz, D.; Mihai, M. Porous thiourea-grafted-chitosan hydrogels: Synthesis and sorption of toxic metal ions from contaminated waters. Colloids Surf. A 2020, 607, 125504. [CrossRef]

22. Cai, L.; Ying, D.; Liang, X.; Zhu, M.; Lin, X.; Xu, Q.; Cai, Z.; Xu, X.; Zhang, L. A novel cationic polyelectrolyte microsphere for ultrafast and ultra-efficient removal of heavy metal ions and dyes. Chem. Eng. J. 2021, 410, 128404. [CrossRef]

23. Fan, S.; Liu, Z.; Wu, Y.; Zhang, Y.; Hu, H.; Huang, Z.; Qin, Y.; Liang, J. 3D porous tubular network-structured chitosan-based beads with multifunctional groups: Highly efficient and selective removal of $\mathrm{Cu}^{2+}$. Int. J. Biol. Macromol. 2021, 171, 17-27. [CrossRef] [PubMed]

24. Maia, M.T.; Sena, D.N.; Calais, G.B.; Luna, F.M.T.; Beppu, M.M.; Vieira, R.S. Effects of histidine modification of chitosan microparticles on metal ion adsorption. React. Funct. Polym. 2020, 154, 104694. [CrossRef]

25. Monier, M.; Bukhari, A.A.H.; Elsayed, N.H. Designing and characterization of copper (II) ion-imprinted adsorbent based on isatin functionalized chitosan. Int. J. Biol. Macromol. 2020, 155, 795-804. [CrossRef]

26. Nikiforova, T.E.; Kozlov, V.A.; Telegin, F.Y. Chemisorption of copper ions in aqueous acidic solutions by modified chitosan. Mater Sci. Eng. B 2021, 263, 114778. [CrossRef]

27. Upadhyay, U.; Sreedhar, I.; Singh, S.A.; Patel, C.M.; Anitha, K.L. Recent advances in heavy metal removal by chitosan based adsorbents. Carbohydr. Polym. 2021, 251, 117000. [CrossRef] [PubMed]

28. Qi, X.; Liu, R.; Chen, M.; Li, Z.; Qin, T.; Qian, Y.; Zhao, S.; Liu, M.; Zeng, Q.; Shen, J. Removal of copper ions from water using polysaccharide-constructed hydrogels. Carbohydr. Polym. 2019, 209, 101-110. [CrossRef]

29. Zeng, Q.; Qi, X.; Zhang, M.; Tong, X.; Jiang, N.; Pan, W.; Xiong, W.; Li, Y.; Xu, J.; Shen, J.; et al. Efficient decontamination of heavy metals from aqueous solution using pullulan/polydopamine hydrogels. Int. J. Biol. Macromol. 2020, 145, 1049-1058. [CrossRef]

30. Dinu, M.V.; Dinu, I.A.; Lazar, M.M.; Dragan, E.S. Chitosan-based ion-imprinted cryo-composites with excellent selectivity for copper ions. Carbohydr. Polym. 2018, 186, 140-149. [CrossRef]

31. Humelnicu, D.; Lazar, M.M.; Ignat, M.; Dinu, I.A.; Dragan, E.S.; Dinu, M.V. Removal of heavy metal ions from multi-component aqueous solutions by eco-friendly and low-cost composite sorbents with anisotropic pores. J. Hazard. Mater. 2020, 381, 120980. [CrossRef] [PubMed]

32. Sáez, P.; Dinu, I.A.; Rodríguez, A.; Gómez, J.M.; Lazar, M.M.; Rossini, D.; Dinu, M.V. Composite cryo-beads of chitosan reinforced with natural zeolites with remarkable elasticity and switching on/off selectivity for heavy metal ions. Int. J. Biol. Macromol. 2020, 164, 2432-2449. [CrossRef]

33. Mo, Y.; Zhang, Y.; Vincent, T.; Faur, C.; Guibal, E. Investigation of mercury(II) and copper(II) sorption in single and binary systems by alginate/polyethylenimine membranes. Carbohydr. Polym. 2021, 257, 117588. [CrossRef]

34. Goher, M.E.; Hassan, A.M.; Abdel-Moniem, I.A.; Fahmy, A.H.; Abdo, M.H.; El-sayed, S.M. Removal of aluminum, iron and manganese ions from industrial wastes using granular activated carbon and Amberlite IR-120H. Egypt. J. Aquat. Res. 2015, 41, 155-164. [CrossRef]

35. Bouhamed, F.; Elouear, Z.; Bouzid, J.; Ouddane, B. Multi-component adsorption of copper, nickel and zinc from aqueous solutions onto activated carbon prepared from date stones. Environ. Sci. Pollut. Res. 2015, 23, 15801-15806. [CrossRef]

36. Swayampakulaa, K.; Boddub, V.M.; Nadavala, S.K.; Abburi, K. Competitive adsorption of Cu (II), Co (II) and Ni (II) from their binary and tertiary aqueous solutions using chitosan-coated perlite beads as biosorbent. J. Hazard. Mater. 2009, 170, 680-689. [CrossRef] [PubMed]

37. Duan, J.-X.; Li, X.; Zhang, C.-C. The synthesis and adsorption performance of polyamine $\mathrm{Cu}^{2+}$ imprinted polymer for selective removal of $\mathrm{Cu}^{2+}$. Polym. Bull. 2017, 74, 3487-3504. [CrossRef] 
38. Mureseanu, M.; Reiss, A.; Stefanescu, I.; David, E.; Parvulescu, V.; Renard, G.; Hulea, V. Modified SBA-15 mesoporous silica for heavy metal ions remediation. Chemosphere 2008, 73, 1499-1504. [CrossRef] [PubMed]

39. Orakdogen, N. Novel responsive poly(n,n-dimethylaminoethyl methacrylate) gel beads: Preparation, mechanical properties and ph-dependent swelling behavior. J. Polym. Res. 2012, 19, 9914. [CrossRef]

40. Lazar, M.M.; Dinu, I.A.; Dinu, M.V. Synthesis of ethylenediaminetetraacetic acid-functionalized chitosan cryogels as potential sorbents of heavy metal ions. Mater. Plast. 2021, 58, 155-166. [CrossRef] 